\title{
Field Trip Guide to the Valles Caldera and Its Geothermal Systems
}

\author{
Fraser E. Goff \\ Stephen L. Bolivar
}

\section{DISCLAIMER}

\begin{abstract}
This report was prepared as an account of work sponsored by an agency of the United States Government. Neither the United States Government nor any agency thereof, nor any of their employees, makes any warranty, express or implied, or assumes any legal liability or responsibility for the accuracy, completeness, or usefulness of any information, apparatus, product, or process disclosed, or represents that its use would not infringe privately owned rights. Reference herein to any specific commercial product, process, or service by trade name, trademark, manufacturer, or otherwise does not necessarily constitute or imply its endorsement, recommendation, or favoring by the United States Government or any agency thereof. The views and opinions of authors expressed herein do not necessarily state or reflect those of the United States Government or any agency thereof.
\end{abstract}




\section{DISCLAIMER}

This report was prepared as an account of work sponsored by an agency of the United States Government. Neither the United States Government nor any agency Thereof, nor any of their employees, makes any warranty, express or implied, or assumes any legal liability or responsibility for the accuracy, completeness, or usefulness of any information, apparatus, product, or process disclosed, or represents that its use would not infringe privately owned rights. Reference herein to any specific commercial product, process, or service by trade name, trademark, manufacturer, or otherwise does not necessarily constitute or imply its endorsement, recommendation, or favoring by the United States Government or any agency thereof. The views and opinions of authors expressed herein do not necessarily state or reflect those of the United States Government or any agency thereof. 


\section{DISCLAIMER}

Portions of this document may be illegible in electronic image products. Images are produced from the best available original document. 
FIELD TRIP GUIDE TO THE VALLES CALDERA

AND ITS GEOTHERMAL SYSTEMS

by

Fraser E. Goff and Stephen L. Bolivar

\begin{abstract}
This field trip guide has been compiled from extensive field trips led by the authors and colleagues at Los Alamos National Laboratory during the past six years. The original version of this guide was designed to augment a workshop on the Valles Caldera for the Continental Scientific Drilling Program (CSDP). This workshop was held at Los Alamos, New Mexico, 5-7 October, 1982. We have added more stops to this guide to display the volcanic and geothermal features at the Valles Caldera. The trip covers about 90 miles (one way) and takes two days to complete; however, those who wish to compress the trip into one day are advised to use the designated stops listed in the Introduction. Valles Caldera and vicinity comprise both one of the most exciting geothermal areas in the United States and one of the best preserved Quaternary caldera complexes in the world.
\end{abstract}




\section{INTRODUCTION}

This log begins at the parking lot of the Hilltop House motel in Los Alamos, New Mexico. The general route will take you along the Pajarito Plateau, into the Valles Caldera, and down to Jemez Springs. The Valles Caldera, Jemez Mountains, relationship of the Rio Grande rift to the caldera, volcanic stratigraphy, geophysics, structure, and hydrothermal systems of the area will be described at the respective stops. If you are interested in a compressed one-day field trip, stop only at those locations designated by *. The trip covers about 90 miles (one way), however mileages vary depending on vehicle used, therefore please recheck your mileage at obvious reference points.

NOTE: STOPS 10 AND 11 ARE ON PRIVATE PROPERTY AND REQUIRE PERMISSION 'OF OWNERS TO ENTER. DO NOT TRESPASS.

*STOP 1 GUAJE PUMICE AND LATE TERTIARY STRATIGRAPHY

*STOP 2 WHITE ROCK CANYON OVERLOOK

STOP 3 BANDELIER TUFF, ANCHO CANYON

STOP 4 TA-33 CANYON OVERLOOK

STOP 5 FLOW UNITS IN WELDED UPPER BANDELIER TUFF

STOP 6 PAJARITO PLATEAU OVERLOOK AND PAJARITO FAULT

*STOP 7 VALLE GRANDE OVERLOOK

STOP 8 SOUTH MOUNTAIN RHYOLITE AND HYDROTHERMALLY ALTERED PALIZA CANYON BASALT

*STOP 9 MOAT RHYOLITE STRATIGRAPHY

*STOP 10 REDONDO CREEK GRABEN; BACA \#12 WELL PAD

*STOP 11 SULPHUR SPRINGS

STOP 12 SAN ANTONIO HOT SPRING

*STOP 13 WEST CALDERA OVERLOOK

*STOP 14 FENTON HILL HOT DRY ROCK SITE

STOP 15 BATTLESHIP ROCK

*STOP 16 SODA DAM AND JEMEZ FAULT ZONE

STOP 17 JEMEZ SPRINGS, DINNER AT LOS OJOS 
Overview

The Valles Caldera occurs in the Jemez (Hay-mez) Mountains Volcanic Field in north-central New Mexico, where C. S. Ross, R. L. Smith, and R. A. Bailey (initially) developed the coneept of resurgent calderas (Smith and Bailey 1968). Surrounding plateaus are capped by ash-flow sheets of Bandelier Tuff, which erupted during caldera formation.

Volcanism in the Jemez Mountains is bracketed between $>13$ Myr and $<0.1$ Myr (Bailey et al. 1969; Gardner 1983). With eruptions of large volumes of Bandelier Tuff, the roof of the magma chamber caved in 1.4 Myr ago forming the Toledo Caldera and again at 1.1 Myr forming the Valles Caldera. This younger caldera, which is about $19 \mathrm{~km}$ in diameter, obscures the Toledo Caldera. After the later collapse several late-stage rhyolite domes extruded along ring faults around Redondo Peak, a large resurgent dome. Several intermontane basins surround this dome; the best known being the Valle Grande.

The Jemez Mountains lie at the intersection of the volcanically active Jemez Lineament and the tectonically active Rio Grande rift (Figs. 1-3). The Jemez Lineament is defined as the alignment of Late-Cenozoic volcanic fields (Laughlin et al. 1972; Mayo 1958). Volcanism along the Jemez Lineament has been continuous since Pliocene time. Although intermediate and silicic rocks dominate the Jemez Mountains and nearby Mt. Taylor volcanic fields, most of the volcanism along the lineament has produced basaltic rocks. There are no consistent time or compositional trends along the Jemez Lineament (Laughlin et al. 1976). The largest volume of volcanics erupted in the Jemez Mountains.

Volcanic history of the Jemez Mountains and surrounding vicinity is very complex. Bailey et al. (1969) have divided the volcanic evolution of the Jemez Mountains into 3 major groups (Figs. 4 and 5 ). The Keres Group is dominated by andesitic lavas of the Paliza Canyon Formation. Basaltic through rhyolitic rocks are al so present. Ages range from $>13$ to $<7$ Myr and original volume probably exceeded $1000 \mathrm{~km}^{3}$ (Gardner 1983). Present exposures of these rocks lie mostly south of Valles Caldera, al though Union 0il Co. drilled $400 \mathrm{~m}$ of these rocks inside the caldera. The Polvadera Group contains predominantly latitic rocks of the Tschicoma Formation. These rocks range from about 6.5 to 2 Myr and original volume probably exceeded $500 \mathrm{~km}^{3}$. The Tewa Group includes Toledo and Valles Calderas, their associated rhyolites, and the Upper and Lower Bandelier Tuff. The Toledo Caldera formed 1.4 Myr ago whereas Valles Caldera formed $1.1 \mathrm{Myr}$ ago. The youngest volcanic rocks in the Jemez Mountains are rhyolites in the southern part of Valles Caldera lless than 100,000 years old).

The present hydrothermal systems of the Valles Caldera are interesting because of their geologic and structural settings and unique chemical and isotopic composition (Goff and Grigsby 1982). A high-temperature neutral chloride geothermal system circulates beneath the resurgent dome of the caldera and derivatives of these fluids leak out to the southwest along the Jemez Fault Zone. Above the deep geothermal system are zones of steam-heated hot springs, most notably, the acid-sulfate springs of Sulphur Springs. Dilute thermal meteoric hot springs discharge from several points in the western moat of the caldera. 
A complete geophysical picture of the caldera and the caldera's relation to the rift has never been published, although many studies have been done on topical problems. Average heat flow along the western rift averages about 2.7 HFU (Heat Flow Units), whereas it locally exceeds 10 HFU within the caldera due to convection (Reiter et al. 1976). Although the Pajarito Fault Zone (a rift fault) is seismically active, Valles Caldera itself appears to be virtually aseismic (D. Cash, Los Alamos, unpub. data, 1982). Union 0il Co. performed a gravity survey of the caldera and their results suggest an asymmetric subsurface structure. This may be due to the overlap of the valles and the earlier Toledo Caldera, or to the intersection of the Jemez Lineament with the pre-existing Rio Grande Rift structure.

Introductory figures are included to help orient the visitor. Figure 1 shows the regional features, Fig. 2 includes major rift-related structures, Fig. 3 (with overlay), shows major geographic features on LANDSAT imagery, and Fig. 4 displays all stop locations. Figure 5 shows the stratigraphic nomenclature and general chronologic relations of volcanic and associated volcaniclastic rocks of the Jemez Mountains.

\section{ACKNOWLEDGMENTS}

Field trip descriptions for stops $1,3,6,7,8,13$, and 15 are taken verbatim from Bailey and Smith (1978). We wish to thank our colleagues at Los Alamos National Laboratory for enriching our knowledge of the Jemez Mountains and improving the quality of this guide; particularly Grant Heiken, Aaron Waters, Jamie Gardner, Scott Baldridge, Bruce Crowe, A. W. Laughlin, Frank Byers, Dave Broxton, Rosemary Vidale, and Chuck Grigsby. Special thanks to A. W. Laughlin for Fig. 3 and Marcia Jones for typing, Mary Ann 01 son for preparing the cover, Anthony Garcia for drafting, and Robert Riecker for constructive comments. 

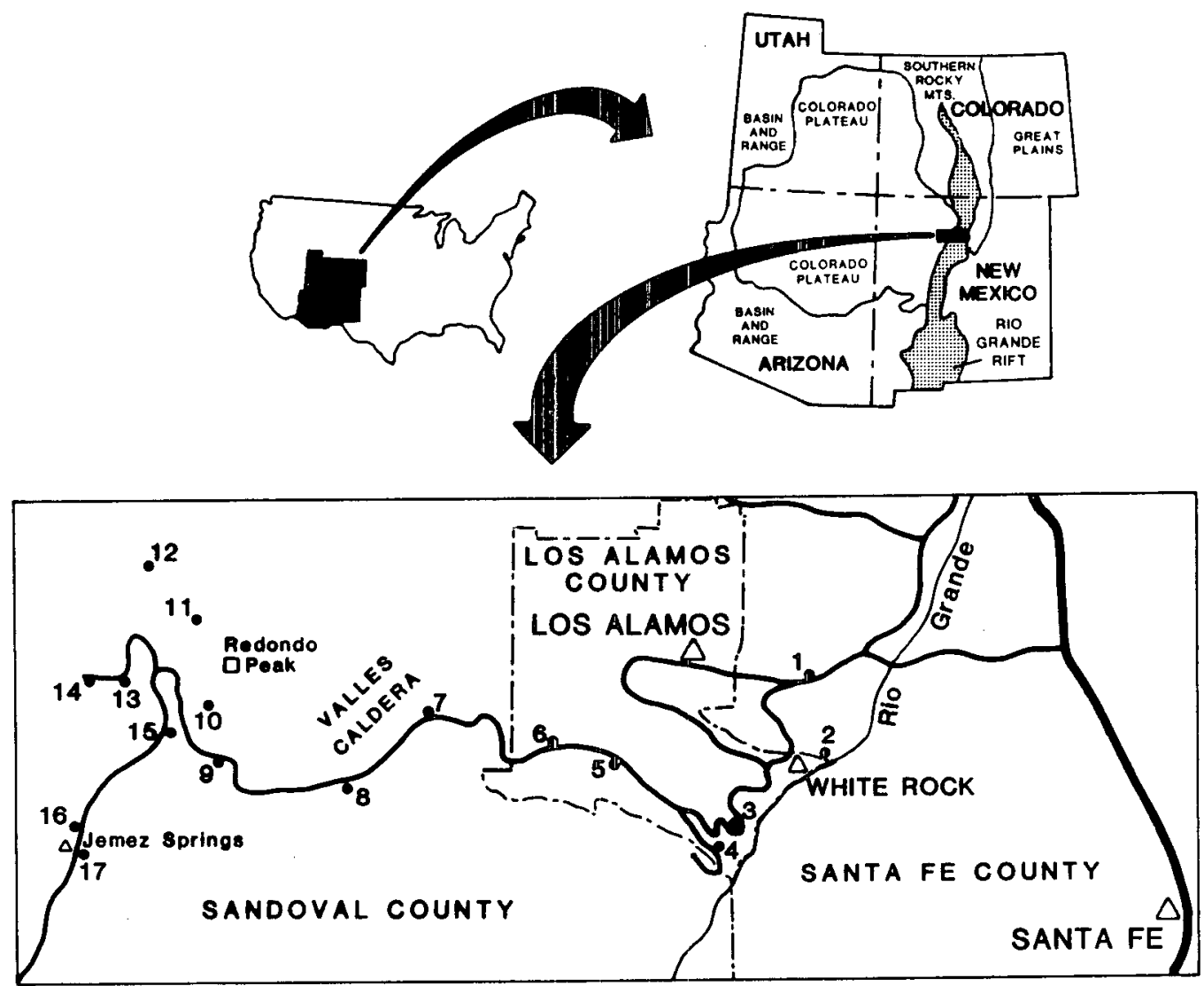

Fig. 1 .

Index map. Upper pictures show the location of the rift (stippled area). Lower picture shows the surrounding region and approximate locations for field trip stops.

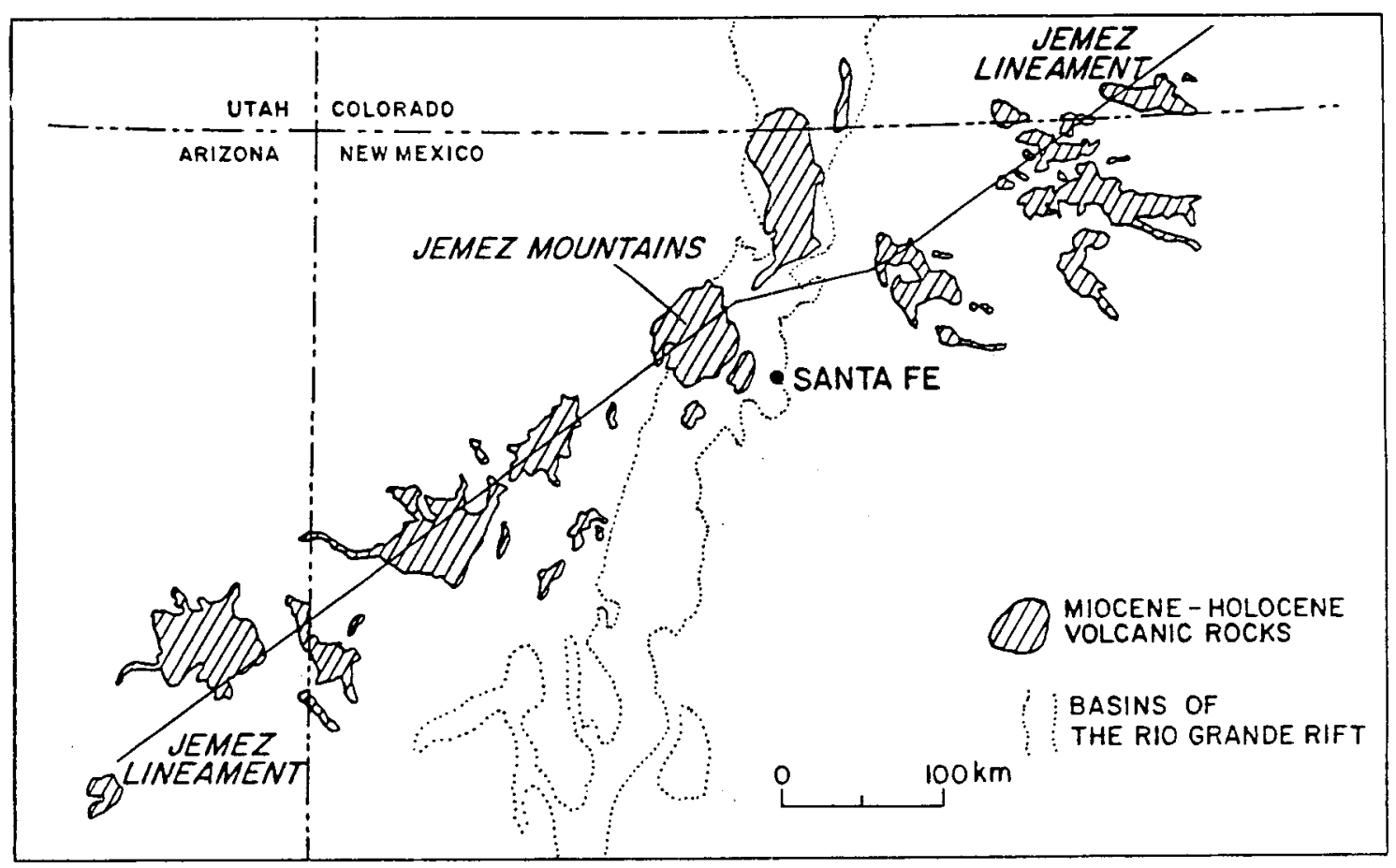

Fig. 2 .

The Jemez Lineament and associated features. 


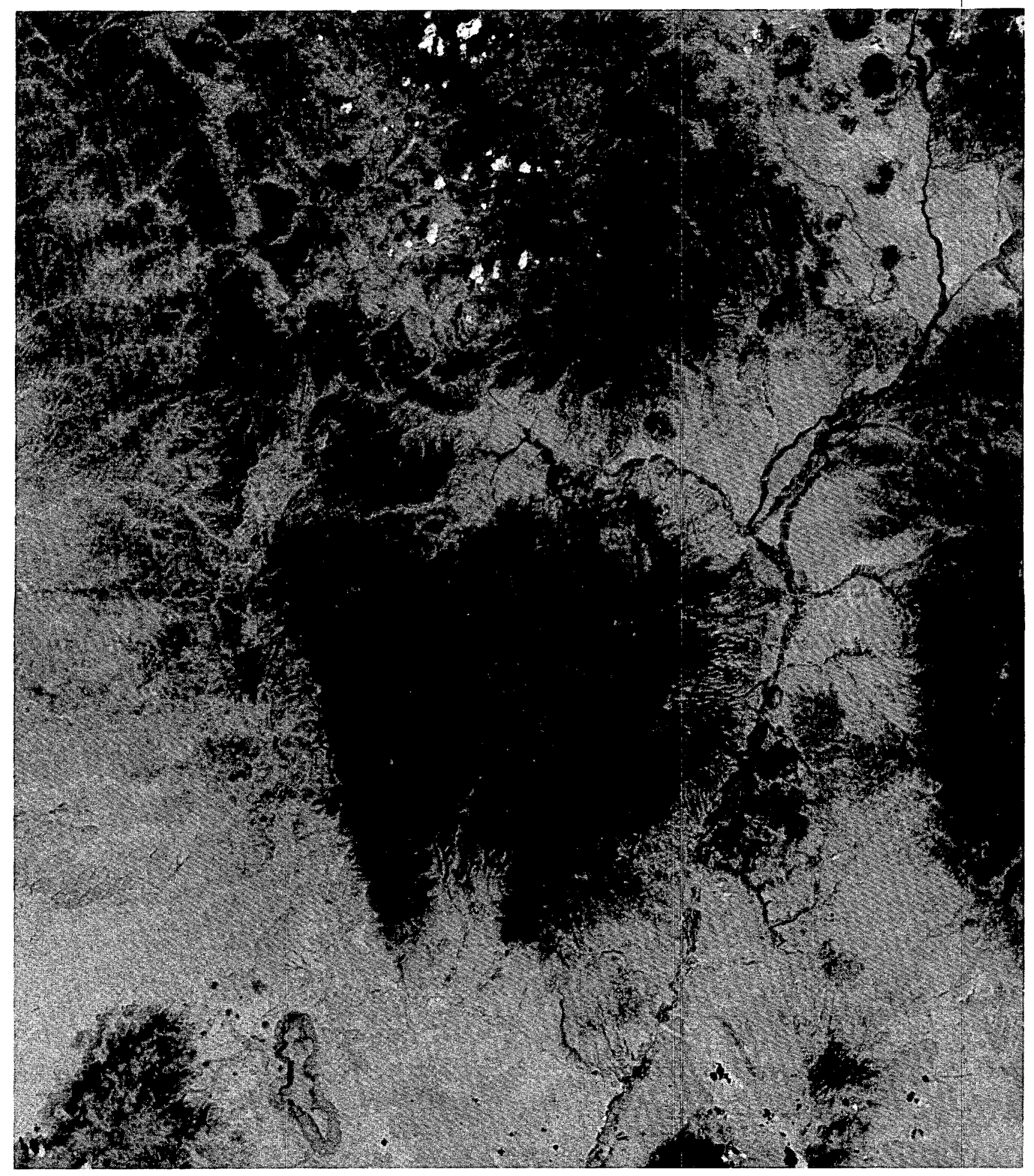

Fig. 3.

LANDSAT photograph (bands 4, 5, 7) for the Valles Caldera and surrounding area. The overlay (in pocket on inside back cover) (modified by Laughtin $1981)$ shows major geographic features. 


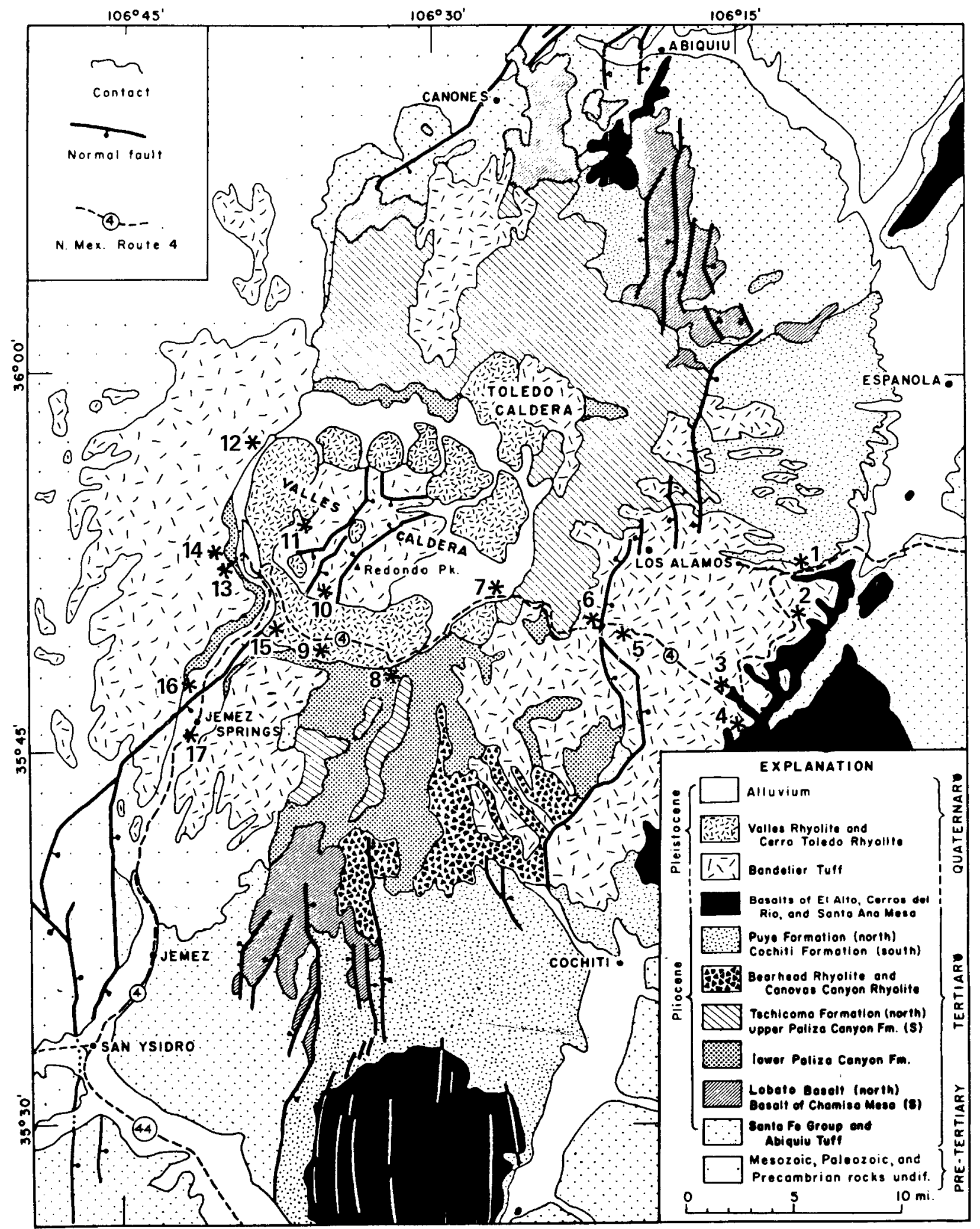

Fig. 4.

Generalized geologic map and stratigraphy of the Jemez Mountains (from Bailey and Smith 1978), showing field trip stops in bold numbers. 


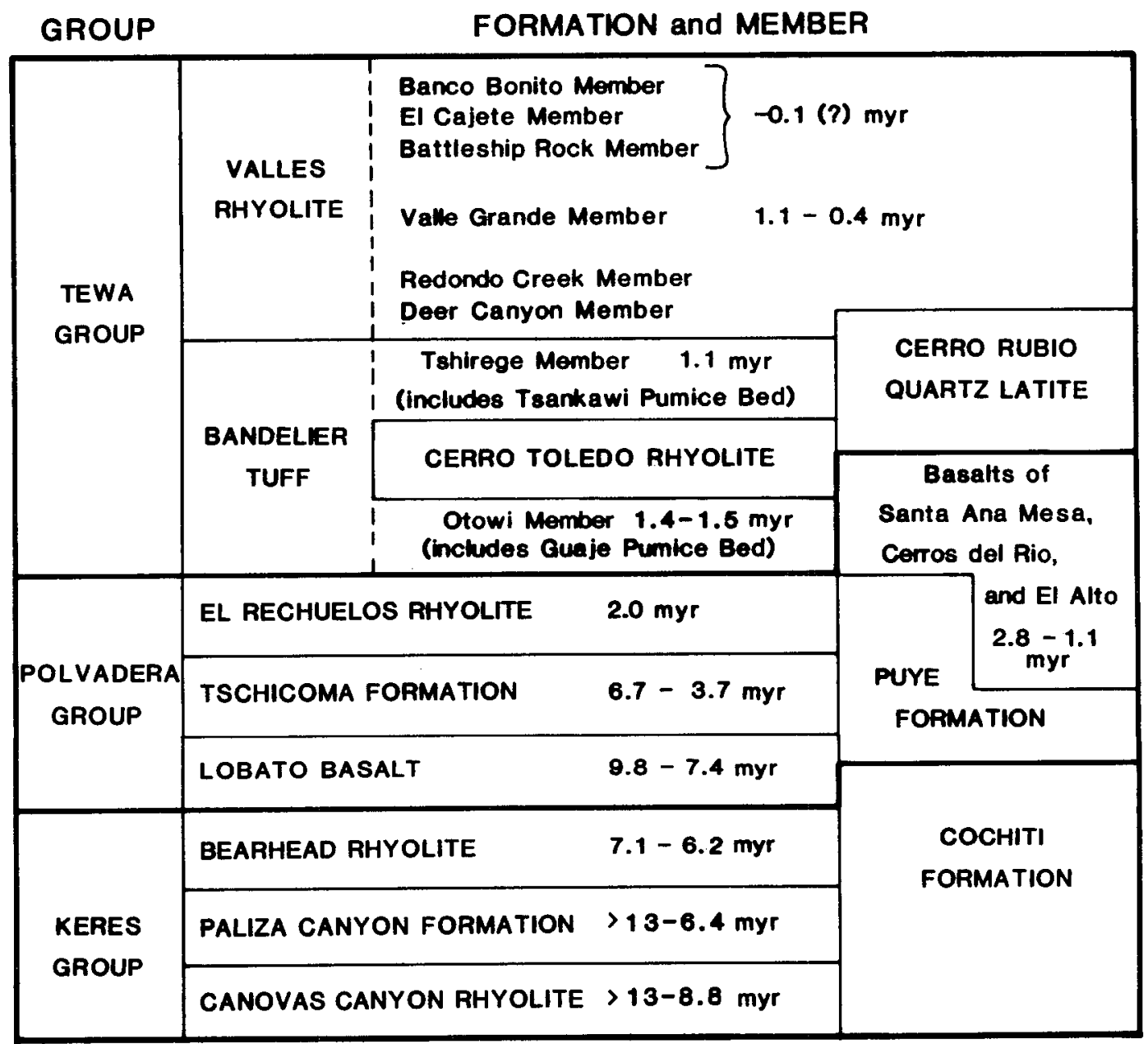

Fig. 5 .

Stratigraphic nomenclature and general chronologic relations of volcanic and associated volcaniclastic rocks. of the Jemez Mountains. Ages show range of $\mathrm{K}-\mathrm{Ar}$ dates available and do not necessarily indicate maximum and minimum ages of formations (modified from Bailey and Smith 1978). 
ROAD LOG

Mi leage

between Cumulative

observations Mileage START FIELD TRIP

$0.0 \quad 0.0 \quad$ Begin field trip in west parking lot, Hilltop House, Los Alamos, New Mexico. Turn left, heading east onto Trinity Drive, loop Highway 4.

1.0

1.0 In the distance (east) are the Sangre de Cristo Mountains forming the east wall of the Rio Grande rift. The snow-capped peaks at 11:00 are Truchas Peaks, elevation $4000 \mathrm{~m}$.

1.0

2.0 Philomena's New Mexican Restaurant and abandoned

1.3 guardhouse.

Sangre de Cristo Mountains

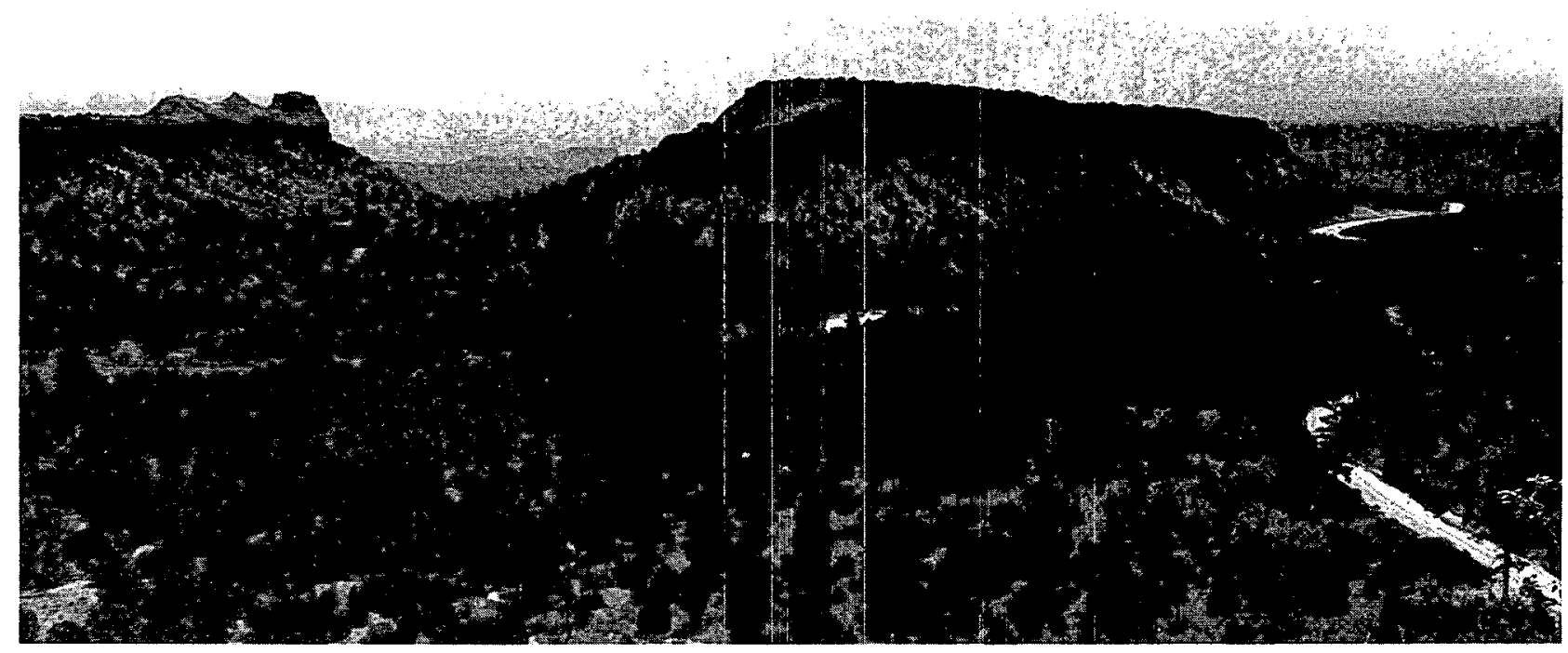

Fig. 6 .

Senator Clinton P. Anderson Memorial Overlook. The cliffs are composed of welded upper Bandelier Tuff. 
Senator Clinton $P$. Anderson Memorial Overlook (Fig. $6)$. The cliffs are composed of the upper member (Tshirege) of Bandelier Tuff. Pink sculptured sediments of the rift can be seen in the middle 1.1 distance between the mesas.

\section{9}

4.4 Junction Truck Highway 4, go straight ahead (east).

5.3 Park in large turn-out, right side of highway at head of Los Alamos Canyon.

*STOP 1: GUAJE PUMICE AND LATE TERTIARY STRATIGRAPHY

Guaje Pumice Bed of the Otowi Member of the Bandelier Tuff (Fig. 7) overlies 2.4 Myr basalt in roadcut on left. Note soil developed on top of basalt. In the slopes and cliffs above the basalt, about $100 \mathrm{~m}$ of Bandelier Tuff is exposed. The Guaje Pumice Bed is about $7 \mathrm{~m}$ thick here, but the bed is commonly as much as $10 \mathrm{~m}$ thick on the east side of the mountains. Underlying the slopes and exposed in gullies to the base of the cliffs are about $50 \mathrm{~m}$ of nonwelded 0towi ash flows. At the base of the cliffs are $1 \mathrm{~m}$ of the Tsankawi Pumice Bed of the Tshirege Member, and above are $50 \mathrm{~m}$ of partly welded Tshirege ash flows. In the upper $30 \mathrm{~m}$ of columnarjointed tuff, at least eight distinct flow units separated by sandy partings and pumice concentrations are discernible.

The basalt underlying the Bandelier at this locality erupted from a vent exposed in the gorge immediately south of the road. The flow grades downward into pillowed palagonite breccia, which displays, in the road below and in the cliffs on the south side of the canyon, remarkable foreset bedding -- an indication that the flow spread eastward from the vent into a lake that probably formed by damming of the Rio Grande elsewhere in the vicinity. About $200 \mathrm{~m}$ down the highway and to the east, water-laid basaltic ash and lacustrine clays underlie the palagonite breccia; the ash and clays provide further evidence of eruption into a former lake. Further down the road, a tongue of basalt at the toe of the flow has injected basalt into sand and gravel beds, causing intense deformation of the sand and gravel. On the north side of this tongue, the basalt was in steep contact with ripple-marked sediments that have since been stripped from the contact, exposing a cast of the ripplemarks in the basalt surface.

To the east and 100-300 $\mathrm{m}$ down the highway, lacustrine clays overlie coarse boulder beds of the Puye 


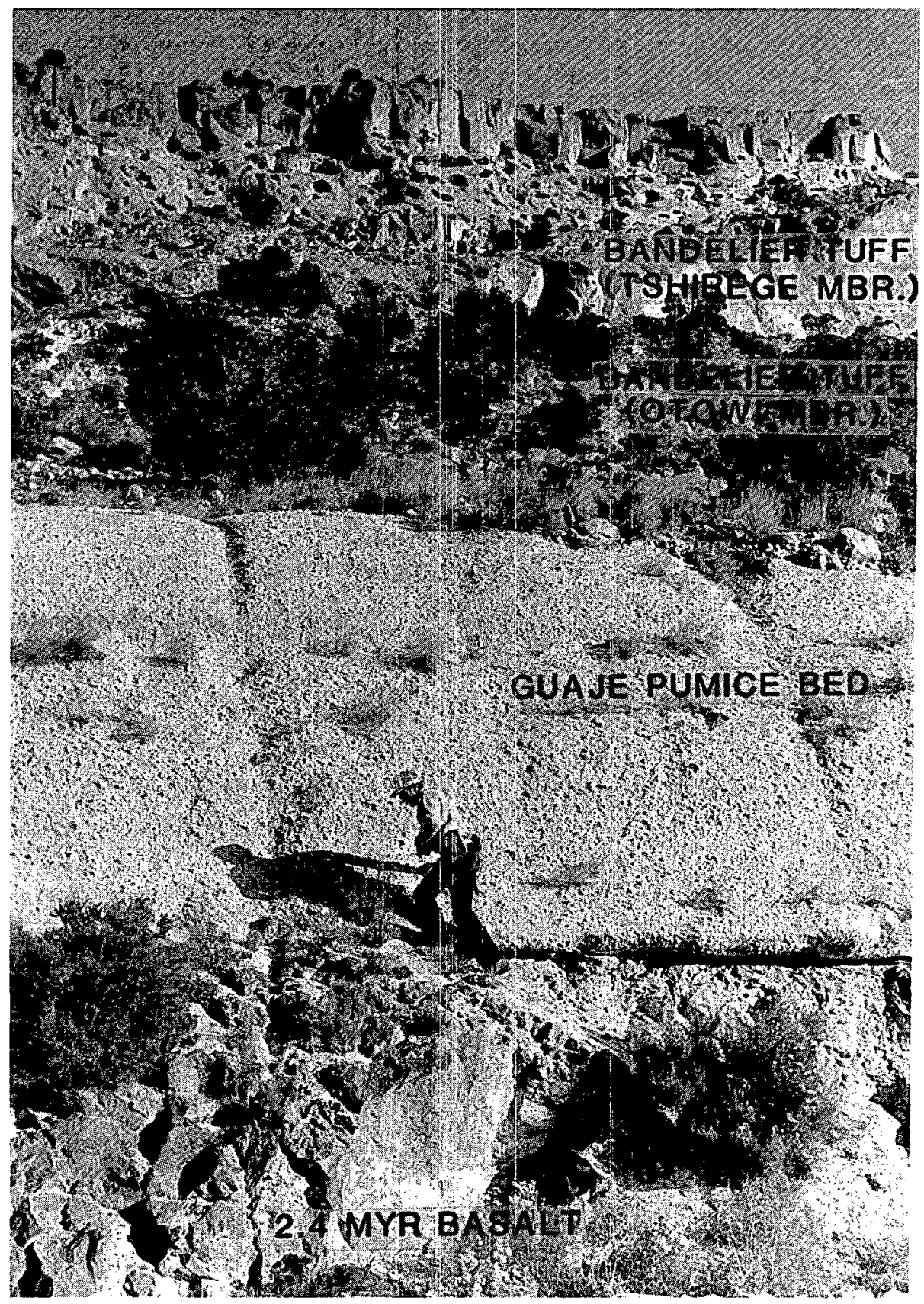

Fig. 7 .

View of Guaje Pumice (1.44 Myr), the airfall member at the base of Lower Bandelier Tuff. The pumice overlies a thin soil horizon, lake deposits and olivine basalt and pillow basalt ( 2.4 Myr) of the Cerros del Rio volcanic field. 
Formation. The Puye is composed mainly of volcaniclastic debris derived from the central and northern Jemez Mountains by rapid erosion of Tschicoma quartz latites and by reworking of associated pyroclastic deposits. Proximal facies of the formation consist largely of lithic pyroclastic and laharic deposits, whereas distal facies are fluvial. The base of the formation contains beds consisting predominantly of well-rounded boulders of Precambrian granite and metamorphic rocks from distant sources. This unit, the Totavi Lentil of the Puye Formation (Griggs 1964), is a channel deposit of the ancestral Rio Grande, which was forced eastward by rapid growth of the huge volcaniclastic fan that forms the Puye Formation.

Turn vehicles around and go west.

0.8

6.1 Junction Loop Highway 4 , turn left on truck route (Highway 4) toward White Rock.

0.9

7.0

Indian caves in upper Bandelier Tuff on right.

0.2

7.2

Tsankawi Indian ruins on left.

0.1

7.3

Junction with truck route to Los Alamos, go straight ahead.

2.7

10.0

White Rock (one of many legends imply town was named after a rock that was painted white so that an army unit could find the location). Turn left onto Rover Blvd.

0.1

10.1

Turn left onto Meadow Lane.

0.9

11.0

Turn left onto Overlook Road; continue past soccer and baseball fields.

0.7

11.7 Park in parking lot.

*STOP 2. WHITE ROCK CANYON OVERLOOK

Walk to end of overlook. To the northeast, through the gap, is Black Mesa (Fig. 8). The isolated mesa due east is La Mesita, a spectacular maar. Behind you, next to the waterfall, is a pillow-palagonite complex (Fig. 9). To the southwest is Bandelier Tuff, landsiide debris, and many slump blocks of basalt (Fig. 10). To the southeast is a plateau and low shield volcanoes, which are part of the earlier Cerros del Rio basalt field (Baldridge 1979). 


\section{6}

13.3 Return to Highway 4, turn left and continue cumulative mileage.

0.9

14.2 Junction Pajarito Road, continue straight on Highway

0.1

14.3 Basalt outcrop of Cerros del Rio field; the low hills to the east are vents for similar basalts.

0.9

15.2 Tsankawi pumice bed over basalt (right side of road).

1.3

1.7

16.5 Small arroyo in basalt. Bandelier Tuff on hillsides.

0.7

18.2

Descend into Ancho Canyon. Bandelier Tuff outcrops.

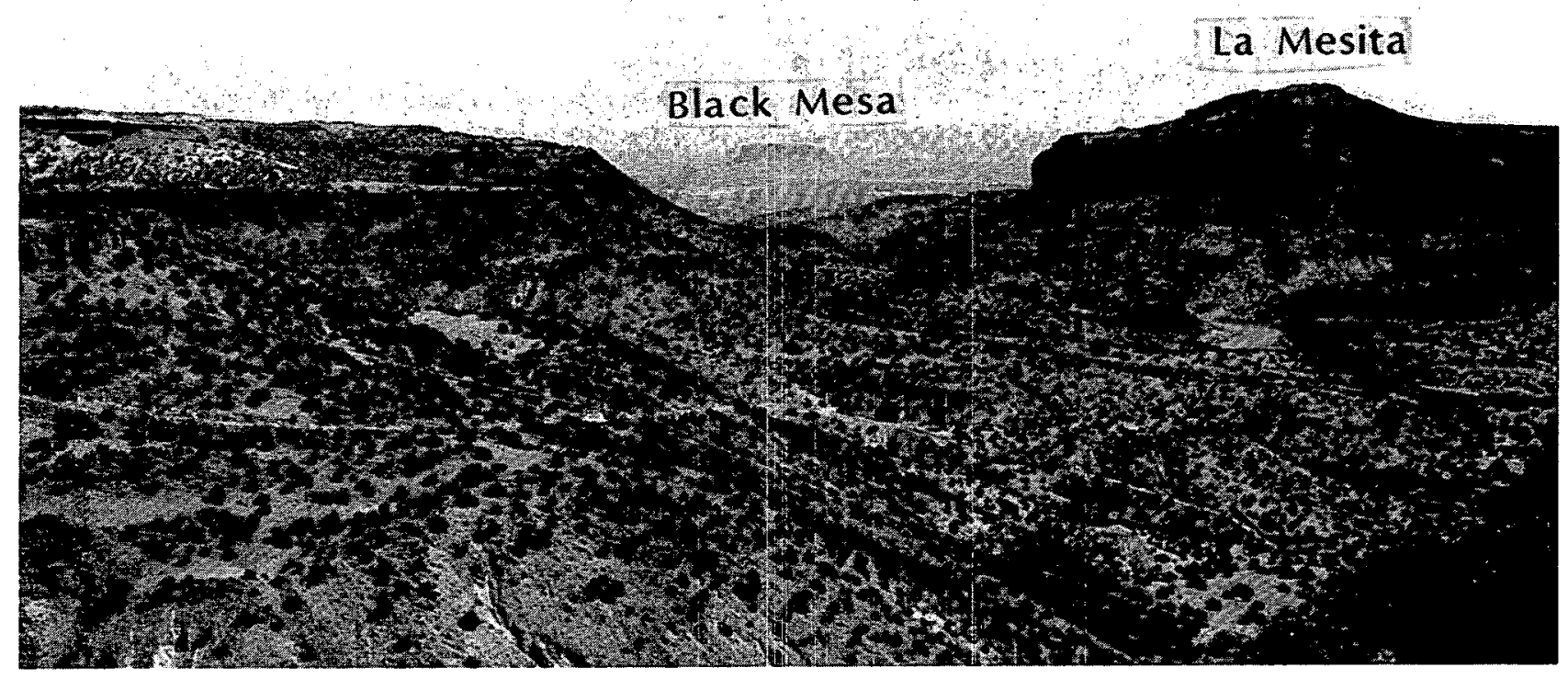

Fig. 8 .

Looking east from White Rock Canyon Overlook. 


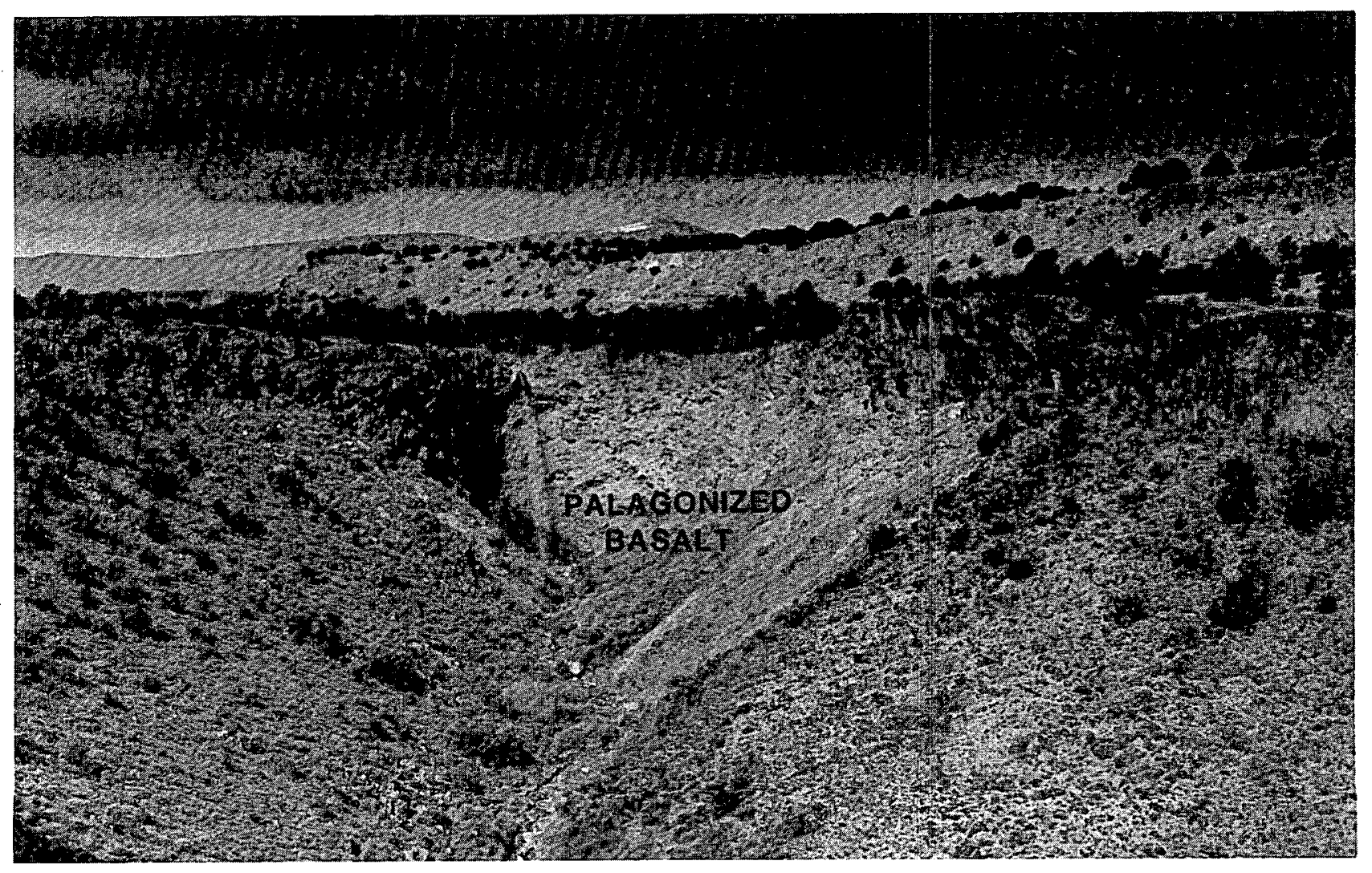

Fig. 9.

Looking northwest towards the Jemez Mountains. The basaltic rocks are heavily palagonized to the right of the stream.

BANDELIER TUFF

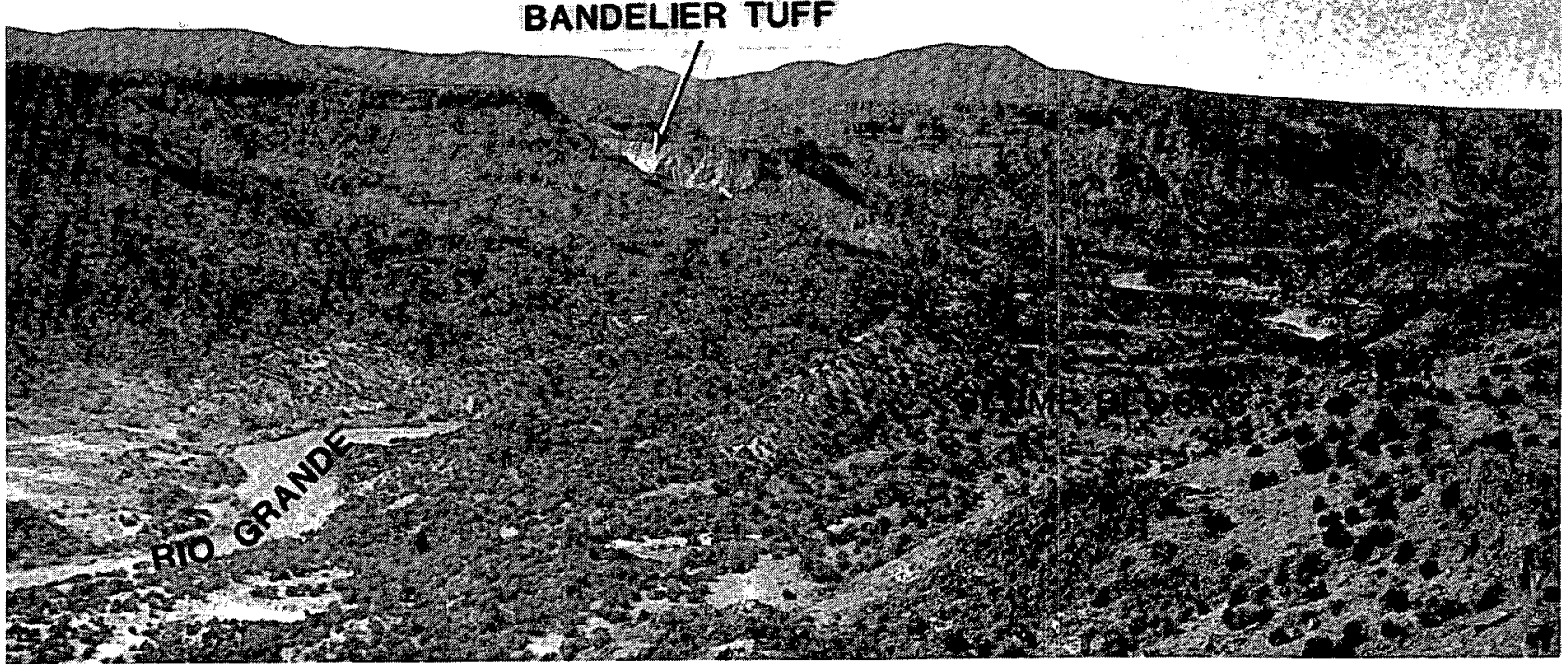

Fig. 10 .

Looking southwest. Slump blocks of basalt and patches of remnant (white) Bandelier can be seen. 
0.3

18.9

19.2

STOP 3:

1.1

20.3 Tech Area 33, turn left through gate, then hard left and go north on paved road (NOTE: THIS AREA IS CLOSED TO VISITORS ON WEEKENDS, HOWEVER WHITE ROCK CANYON OVERLOOK OFFERS SIMILAR SPECTACULAR SCENERY).

1.7

22.0 Turn left on inconspicuous dirt road just before end of pavement.

0.1

22.1 Park in wide area in front of overlook.

STOP 4: TA-33 CANYON OVERLOOK

(DO NOT STOP HERE IF YOU ARE ON A ONE-DAY TRIP.)

White Rock Canyon, more than $600 \mathrm{~m}$ deep, has been cut by the Rio Grande near the distal ends of sheets of Bandelier Tuff. A small outlier of Bandelier Tuff can be seen overlying basalt about $4 \mathrm{~km}$ upstream on the east wall of the canyon. The tuff fills in basalt topography from the Cerros del Rio.

Flows from the Cerros del Rio are mostly basalt and basaltic andesite but include some latites (Baldridge 1979). Interbedded maar deposits seen on canyon walls attest that an ancestral Rio Grande was associated with some of the eruptions. Pink 


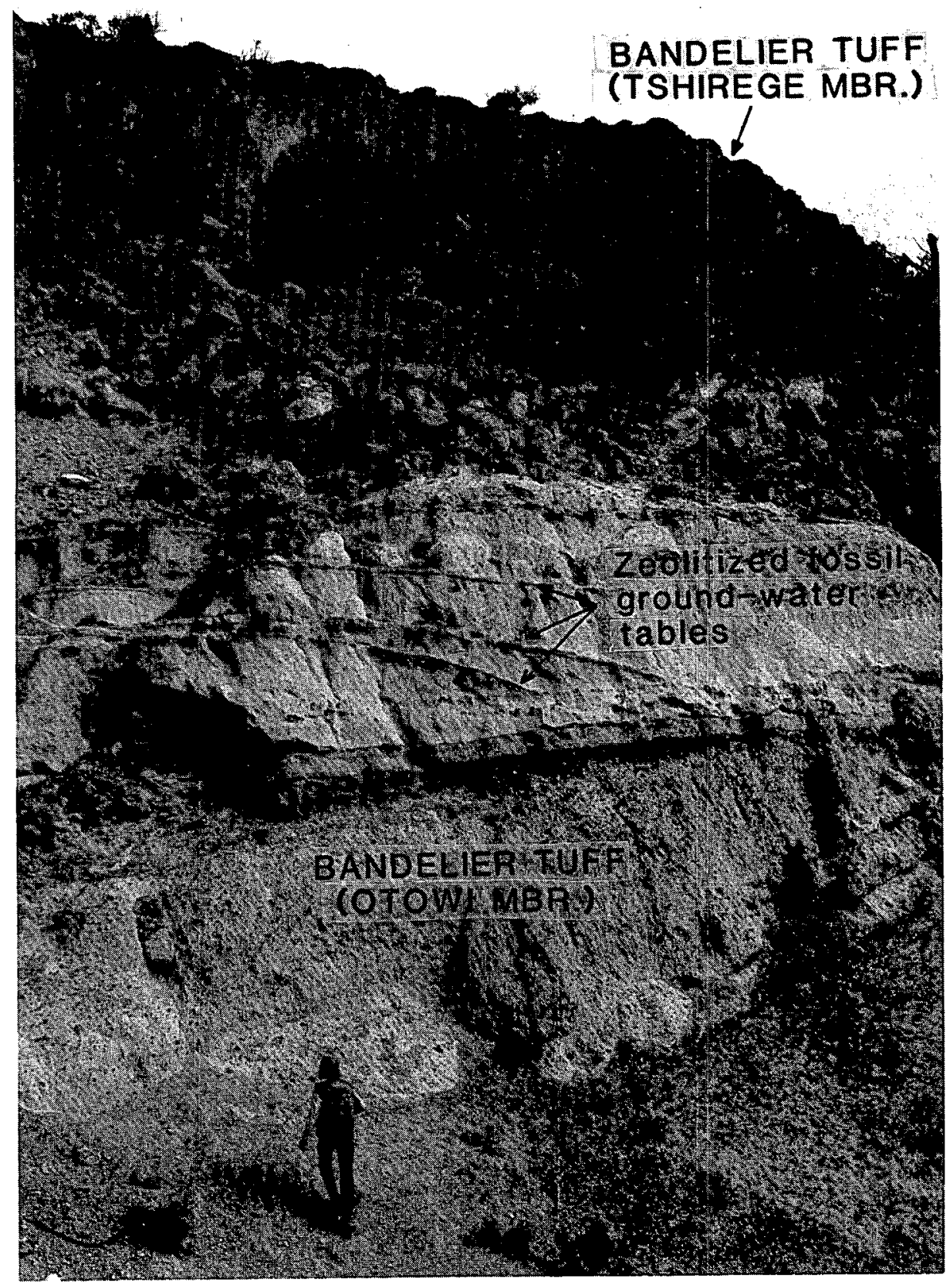

Fig. 11 .

Upper and Lower Bandelier Tuff near Ancho Canyon. 
sediments of the Santa Fe Formation crop out beneath talus on the lower canyon walls.

Large landslide blocks of basalt and unconsolidated Santa Fe Formation have broken off each side of the canyon.

To our left (west) are the large domes of Tschicoma Formation dacites and latites that overlook the Pajarito Plateau and Los Alamos (Fig. 12). Valles Caldera is just beyond to the west.

White Rock Canyon is a favorite of rafters and canoers but it demands skill because of two major rapids.

Turn around and return toward gate at TA-33.

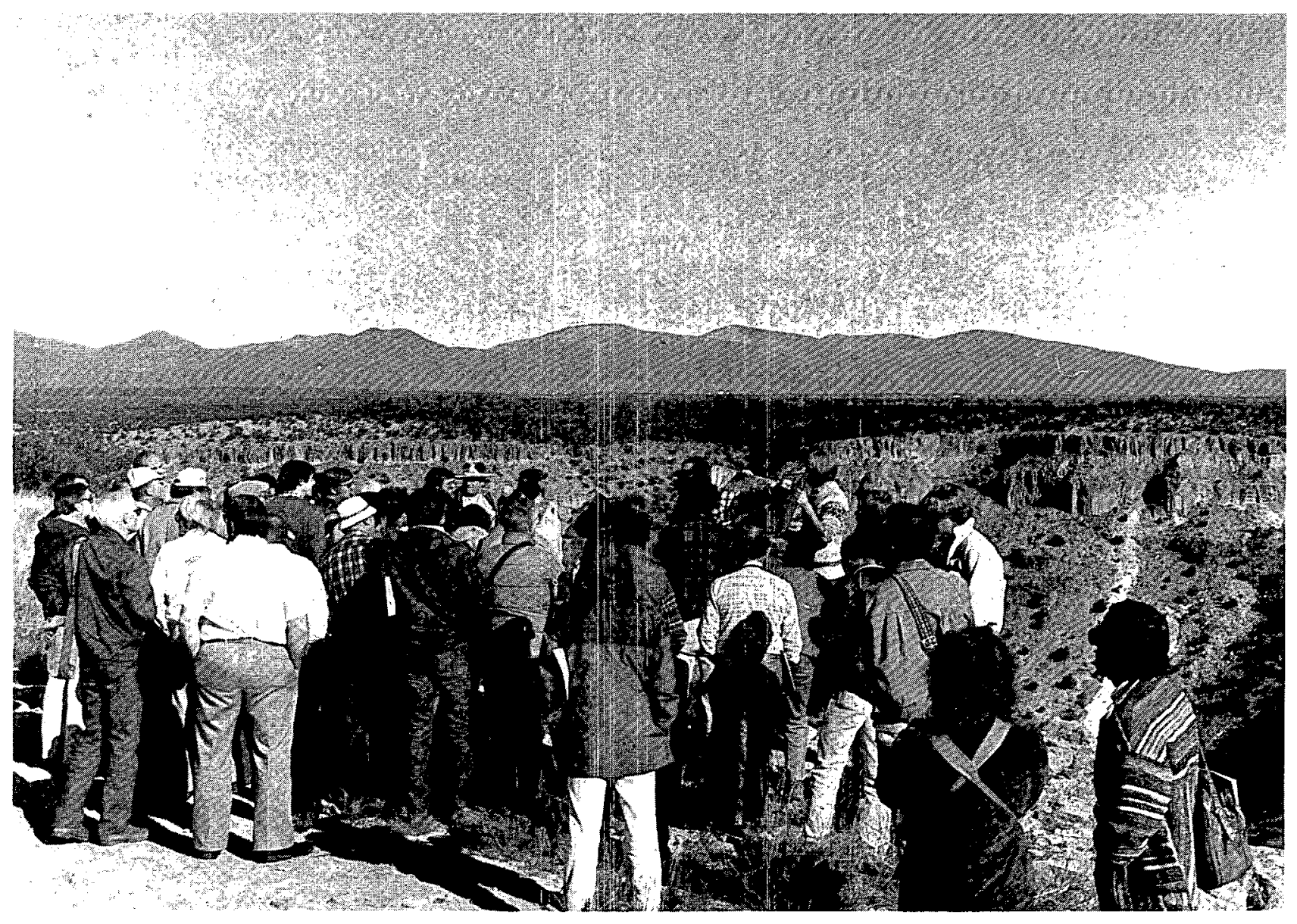

Fig. 12.

View looking northwest across Pajarito Plateau and its cap of upper Bandelier Tuff toward volcanic domes of Sierra Los Valles. 


\section{9}

0.3

24.2

1.0

1.8

2.9

25.2

27.0

Go through gate, TA-33, and turn left (west) on Highway 4.

View of St. Peters Dome at 10 o'clock ( $\sim 8.5$ Myr), pre-caldera volcanic rocks of the Keres Group. The dome is an apparent outlier of Paliza Canyon Formation surrounded by Bandelier Tuff.

Road to Bandelier National Monument on left. We are driving up a gentle dip slope on the eroded surface of Bandelier Tuff.

La Mesa forest fire damage (1977).

29.9

Park in large turnout left side of road; small fault scarp in tuff is part of Pajarito fault zone. Walk up the road about $70 \mathrm{~m}$ to stop 5 .

STOP 5: FLOW UNITS IN WELDED UPPER BANDELIER TUFF

(DO NOT STOP HERE IF YOU ARE ON A ONE-DAY TRIP.)

The internal stratigraphy of the Bandelier Tuff is complex because each member is composed of several flow units erupted in a short space of time that solidified as a compound cooling unit or composite ash-flow sheet. In addition, the magma chamber that erupted Bandelier Tuff is compositionally zoned because early flow units are more silicic and crystal poor ( $5 \%$ phenocrysts) whereas the last flow units are more mafic and crystal rich $(\backsim 30 \%$ phenocrysts). Whereas sanidine and fayalite characterize early flow units, anorthoclase and hypersthene characterized the last flow unit (Doell et al. 1968). At this stop, we can observe about 2-3 m of the welded anorthoclase bearing flow unit separated from a lower flow unit by a few centimeters of base surge material (Fig. 13). The texture of the "anorthoclase unit" changes radically from top to bottom. Note in particular the change in texture of pumice fragments.

Continue west on Highway 4.

1.1

31.0 Junction Highway 4 and Loop Highway 4; go straight up Pajarito fault scarp.

0.6

31.6 Park in small turnout beyond right-angle bend in road. BE CAREFUL OF CARS! 


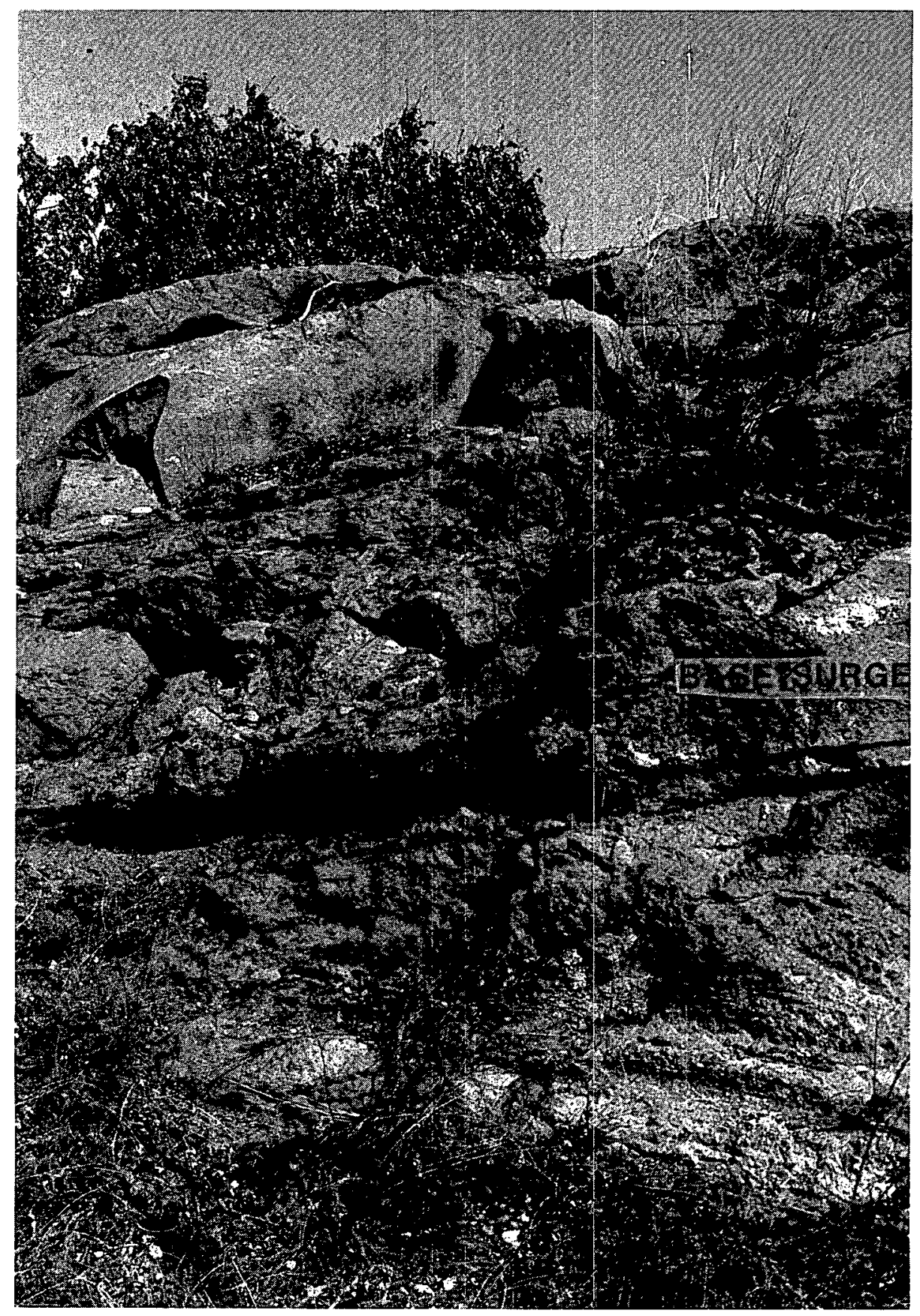

Fig. 13.

Flow units in Upper Bandelier Tuff separated by thin base surge deposit (by notebook). 


$\frac{\text { STOP 6: PAJARITO PLATEAU OVERLOOK AND PAJARITO FAULT }}{\text { (DO NOT STOP HERE IF YOU ARE ON A ONE-DAY TRIP) }}$

Below the escarpment, at the sharp turn in the road, spreads the gently eastward-sloping surface of the Pajarito Plateau, formed of ash-flow deposits of Bandelier Tuff (Fig. 14). In the near distance is White Rock Canyon, gorge of the Rio Grande, and just beyond are the Cerros del Rio, composed of Pliocene and Pleistocene basaltic rocks against which lap the distal ends of the Bandelier Tuff ash flows. On the skyline are the Sangre de Cristo Mountains, which border the east side of the Rio Grande rift.

Ash-flow tuffs of the Pajarito Plateau blanket the southwest segment of the Española Basin, one of the sedimentary basins of the Rio Grande rift. From gravity (Budding 1978), seismic lines (Los Alamos National Laboratory, unpublished data, 1979) and a time-domain electric survey (Williston, McNeal \&

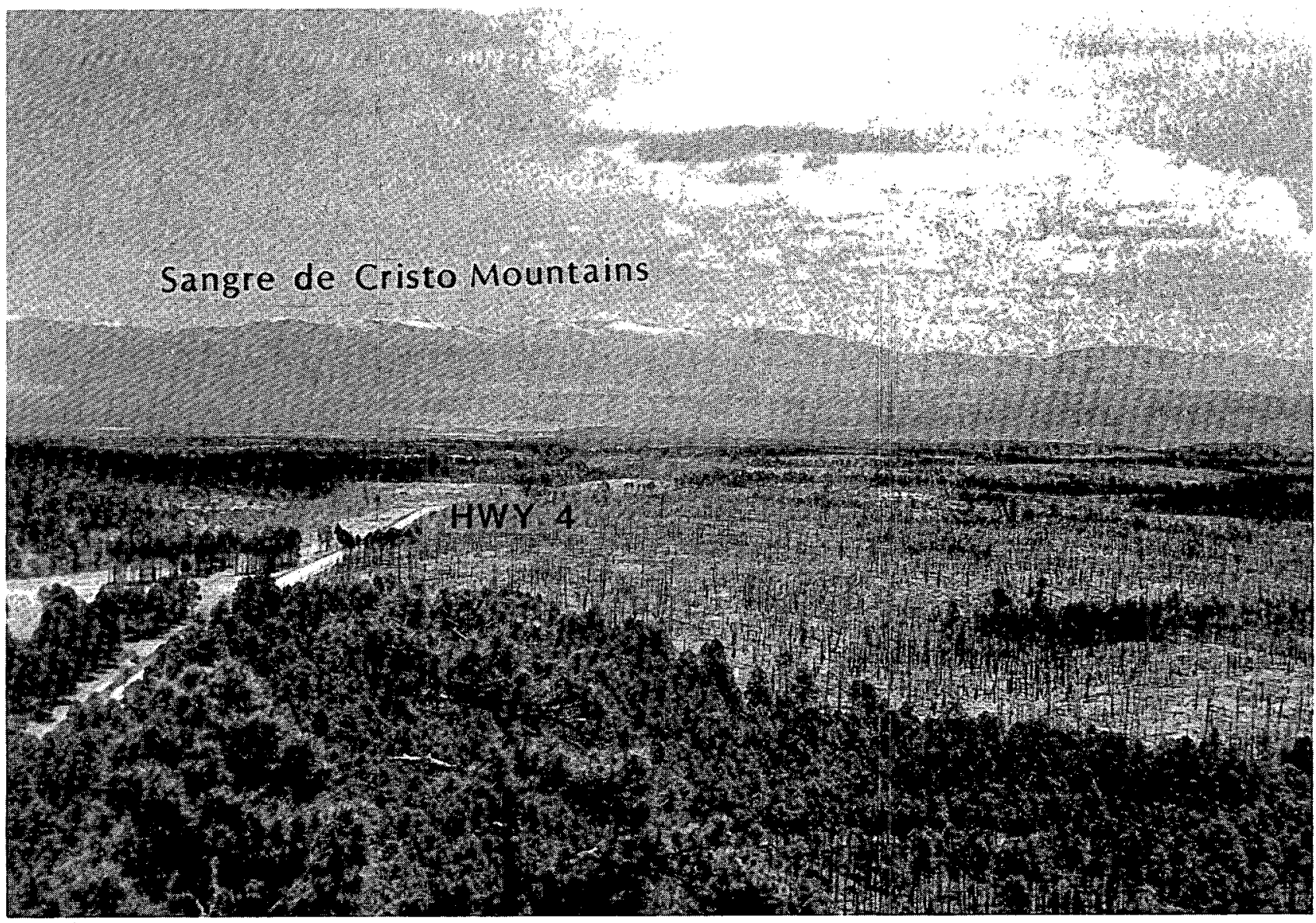

Fig. 14 .

Pajarito Plateau overlook; the Pajarito Fault forms a north-south scarp here. 
Associates 1979), we know that the Española Basin is asymmetric in configuration; being deepest on the west next to the Pajarito Fault and becoming shallower to the east. Depth to Precambrian basement just beyond where we're standing is estimated to be about $3.5 \mathrm{~km}$. A $3-7 \Omega-m$ resistivity low between 2-and $3-\mathrm{km}$ depth adjacent to and east of the fault suggests that warm and/or saline fluids exist in Paleozoic-Mesozoic rocks, probably Madera Limestone above basement. Many seismic reflectors of continuous horizontal extent above the basement interface also suggest up to $1.5 \mathrm{~km}$ of PaleozoicMesozoic rocks. Tertiary fill is estimated to be roughly $1400 \mathrm{~m}$ thick overlain by $600+\mathrm{m}$ of Puye Formation and Bandelier Tuff.

The escarpment at the turn in the road is the Pajarito fault, which extends $50 \mathrm{~km}$ along the east side of the Jemez Mountains and is one of the main displacements on the west side of the Rio Grande rift. The Pajarito fault has been intermittently active throughout pleistocene time and has displaced 3- to 4-Myr latites of the Tschicoma Formation as much as $300 \mathrm{~m}$ and has displaced the Bandelier Tuff 100-150 m. In the roadcuts on the left are several gouge zones between which large blocks of densely welded Bandelier Tuff have been steeply tilted eastward.

Examination of the more gently dipping Bandelier in outcrops $100-500 \mathrm{~m}$ west along the road will reveal two or three thin, sandy partings between densely welded flow units as well as a number of vertical fumarolic pipes containing concentrations of gas-entrained quartz and sanidine phenocrysts. The occurrence of these partings and pipes within such a densely welded unit indicates that both features formed within a very short time span during which the flows remained sufficiently hot to weld together. Each member of the Bandelier Tuff consists of numerous flow units that constitute a compound cooling unit (Smith 1960); however, the multiple-flow character of the Tshirege Member is more conspicuous than that of the Otowi.

The tuff here is more densely welded because of its proximal relation to Valles Caldera. Pumice fragments are flattened and chatoyant blue sanidine phenocrysts are quite obvious.

Continue west on Highway 4. 
Frijoles Canyon on left.

1.5

36.0

Slow, sharp curve.

0.8

36.8

Road to St. Peter's Dome on left.

0.8

37.6

Pass over east lip of Valles Caldera; Redondo Peak in distance.

1.3

38.9

Park in turnout by yellow sign on right side of Highway 4.

*STOP 7: VALLE GRANDE OVERLOOK

The high flat-topped mountain to the west is Redondo Peak, summit of the resurgent dome (Fig. 15). The high knob just to the north (Redondito) and the lower ridge extending northeast (Redondo Extension) also are structural elements of the resurgent dome. All are underlain by densely welded Bandelier Tuff, which dips generally southeast toward the observer. Postcaldera ring domes of Valle Grande Member that are peripheral to the resurgent dome include 0.49 Myr South Mountain, just south of Redondo Peak; 0.50 Myr Cerro La Jara (the small treed knob immediately to its east); and the heavily logged mountains in the middle distance to the north; these mountains, from left to right, include 0.88 Myr Cerro Santa Rosa, 0.89 Myr Cerro del Abrigo, and 1.04 to 1.14 Myr Cerro del Medio.

The rim of the Valles Caldera begins at the far left (southwest), continues behind the observer, and extends to the grass-covered peaks of Cerro Grande and Pajarito Peak on the far right. The red-brown, talus-strewn peak of Cerro Rubio is on the east rim, at its junction with the south rim of the Toledo Caldera. Tschicoma Peak (elevation $3557 \mathrm{~m}$ ), which forms the north rim of the Toledo Caldera, is just visible on the far northeast skyline. The Valles Caldera rim continues northwest out of view behind the heavily logged rhyolite ring domes of Cerro del Medio, Cerros del Abrigo, and Cerro Santa Rosa. The rim is again visible on the far northern skyline, as is the grass-covered face of Cerro de la Garita 18 $\mathrm{km}$ distant.

Rabbit Mountain on the south rim of the valles Caldera is a large rhyolite center temporally and chemically related to the Cerro Toledo Rhyolite, 
This page has been left blank intentionally. 


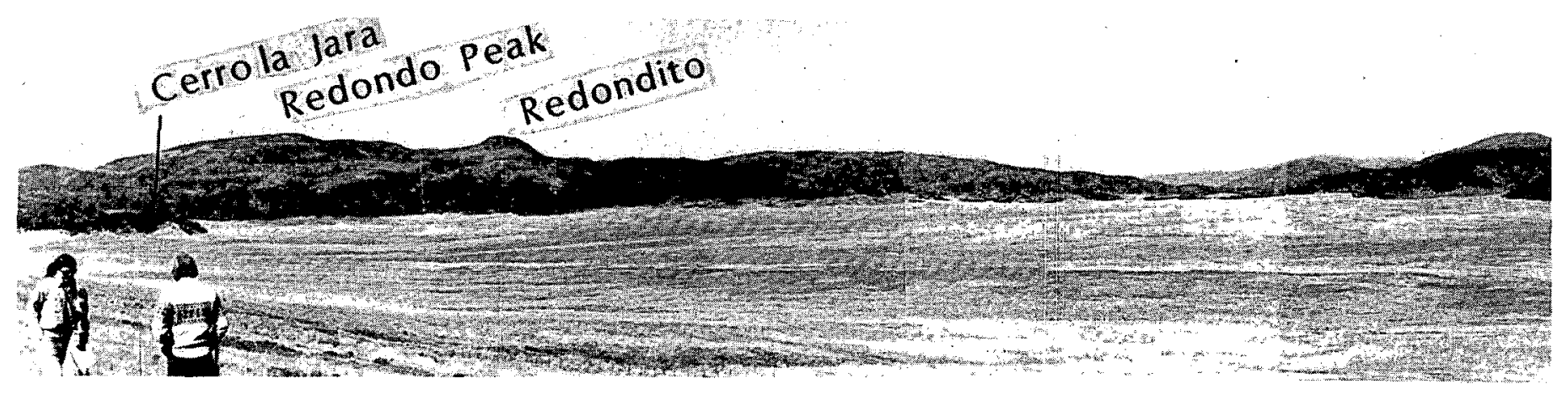

Fig. 15 .

Panoramic view looking west to northwest across Valle Grande toward Redondo Peak, the northern moat rhyolites, and the southern part of Toledo Caldera. 


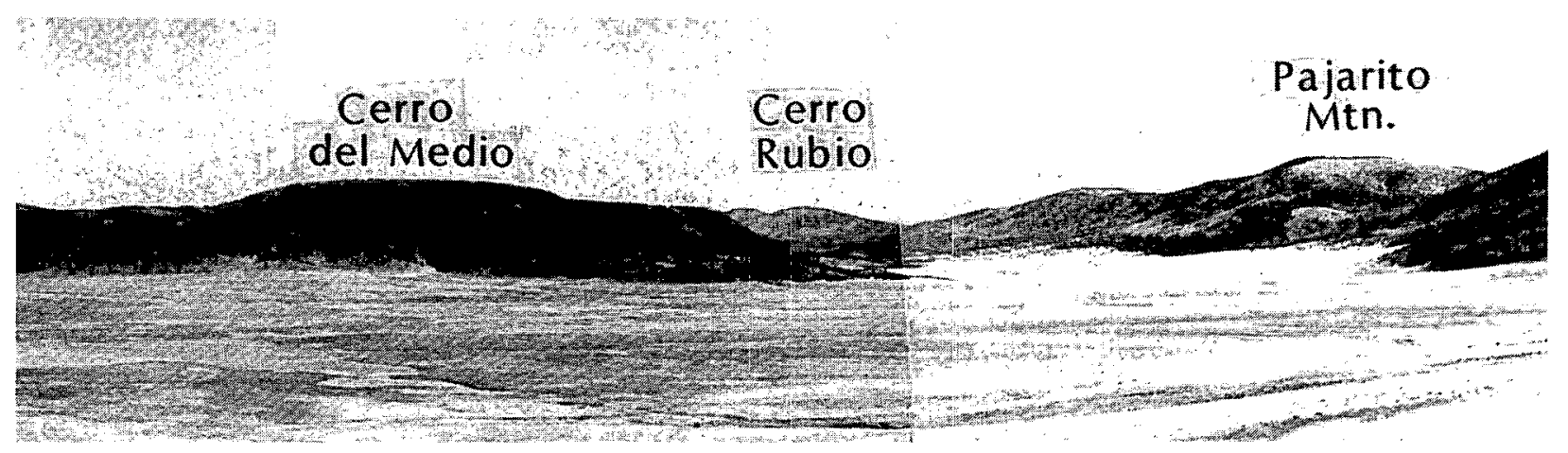


which erupted mainly within the Toledo Caldera between 1.4 and 1.1 Myr ago.

Geothermal development and the cooperative agreement between Union Oil Company of California and the U.S. Department of Energy have made drill hole and geophysical data available to give us a clearer picture of subsurface caldera structure. The most significant information is the gravity report of Segar (1974). His gravity model shows a large negative gravity anomaly centered over the caldera as expected but also shows a northeast-trending zone of lows overlying the Valle Grande-Toledo Caldera area. His data also reveal a series of steep northeast-trending gradients at several locations across the caldera interpreted as precaldera structures (faults) associated with the Rio Grande rift. A northeast-trending horst underlies Redondo Peak but no such structure is apparent beneath Redondo Border on the west side of the medial graben cutting the resurgent dome. A large northeasttrending oval low overlaps the boundary between Valles Caldera and what remains of Toledo Caldera. These data show that pre-existing faults and structure of the rift strongly influence the subsurface structure of the two calderas (Goff 1983).

As a result of the Valles Caldera Workshop (October $5-7,1982)$, sponsored by the Continental Scientific Driliting Program, preliminary geophysical evidence in support of "source magma" at depth is extensive:

(1) Seismic analysis based on chemical explosions detonated near Farmington, New Mexico, shows both $S$ wave and amplitude attenuation, as well as $P$ wave delays and teleseismic frequency changes suggesting anomalies beneath the caldera (01sen et a1. 1983).

(2) The lack of earthquakes under the caldera compared to an otherwise higher regional seismicity is evidence for a change in material behavior in the rocks below the caldera (D. Cash, Los Alamos National Laboratory, personal communication, 1982).

(3) An electrical conductor exists at 10-12 km below the caldera and is coupled with a regional electrical anomaly (Hermance 1979).

(4) The temperature gradient analyses suggest a magmatic heat source (Swanberg 1983).

(5) Perhaps the most compelling evidence concerns the existence of recent volcanism and major hydrothermal systems. 
2.1

0.8

0.8

42.6

1.0

Continue southwest along Highway 4 .

41.0 Road to old gold mining district of Bland on left.

Road to Peralta Canyon on left.

On right are vertically sheeted devitrified cores of rhyolite flows, South Mountain rhyolite.

43.6 Turn right and park in Las Conches campground, which makes a delightful lunch stop.

STOP 8: SOUTH MOUNTAIN RHYOLITE AND HYDROTHERMALLY ALTERED PALIZA CANYON BASALT

TDO NOT STOP HERE IF YOU ARE ON A ONE-DAY TRIP.)

If you examine the rhyolite outcrops across Jemez Creek, the rock displays tiny 1 - to $2-\mathrm{mm}$ spheres of devitrified rock (spheroidal texture) caused by deuteric alterations occurring in the rock after eruption and during cooling. Note the pale pink or grey quartz phenocrysts. Other phenocrysts are plagioclase, sanidine, hornblende, biotite, and clinopyroxene. Crystal-rich rhyolites such as this one (age $=0.49 \mathrm{Myr}$ ) are not uncommon to the moat zone of Valles Caldera. They have erupted along the ring-fracture zone after caldera formation.

The rhyolite flowed over and against caldera wall rocks that have landslid into the caldera depression (Fig. 16). At this point, caldera wall rocks consist of hydrothermally altered basalt of the Paliza Canyon Formation (n8-10 Myr?). Examination of hand specimens shows the original basalt is now dense and greenish black. The reddish-brown blobs are altered olivine phenocrysts. Calcite, quartz, Fe-oxides, and some zeolites fill vugs and fractures. Thin sections show greenschist facies grade of metamorphism with chlorite, albite, sericite, and some epidote replacing original plagioclase, olivine, clinopyroxene, and glass. The age of this alteration is not precisely known. It could be associated with other alteration zones that occur throughout the lower Paliza Canyon Formation or possibly with processes just preceding formation of Valles Caldera. Green alterations such as this occur at a few places along the west and north caldera walls in other precaldera volcanics, but they have never been investigated. 


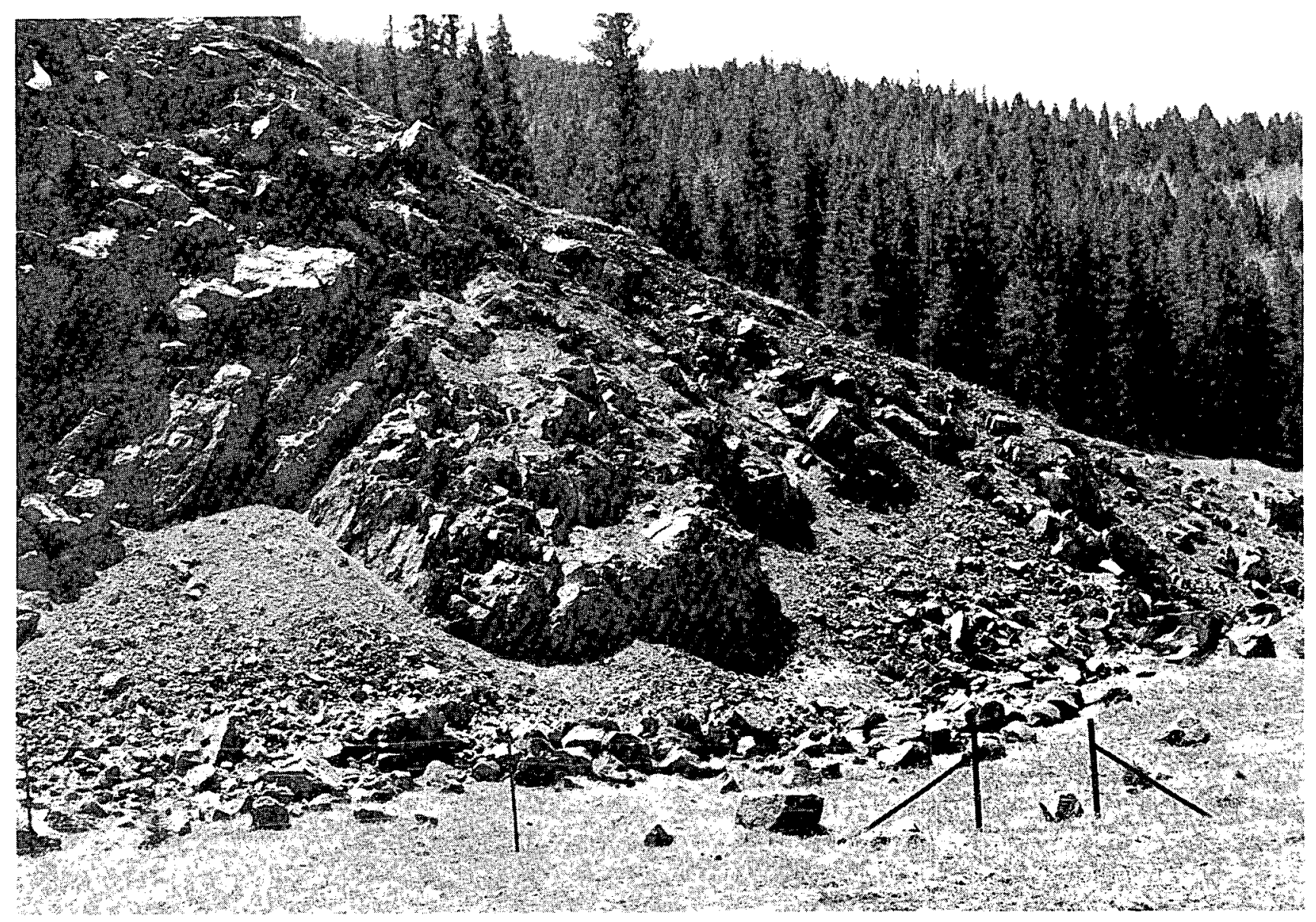

Fig. 16.

Landslide block of hydrothermally altered Paliza Canyon basalt along south caldera wall.
0.9
44.5 We begin driving through a series of outcrops of airfall El Cajete Pumice.
$\begin{array}{ll}1.7 & 46.2 \\ 2.1 & 48.3\end{array}$
Bandelier Tuff on distant horizon.
Park on left side of Highway 4, just beyond creek crossing.
*STOP 9: MOAT RHYOLITE STRATIGRAPHY
Exposed in downward succession in roadcut (Fig. 17) are three members of the Valles Rhyolite: 1) vitro- phyric blocks of the basal part of Banco Bonito glass flow, 2) well-bedded pumice and ash of El Cajete Pumice, and 3) South Mountain Rhyolite flow.

Continue west on Highway 4. 


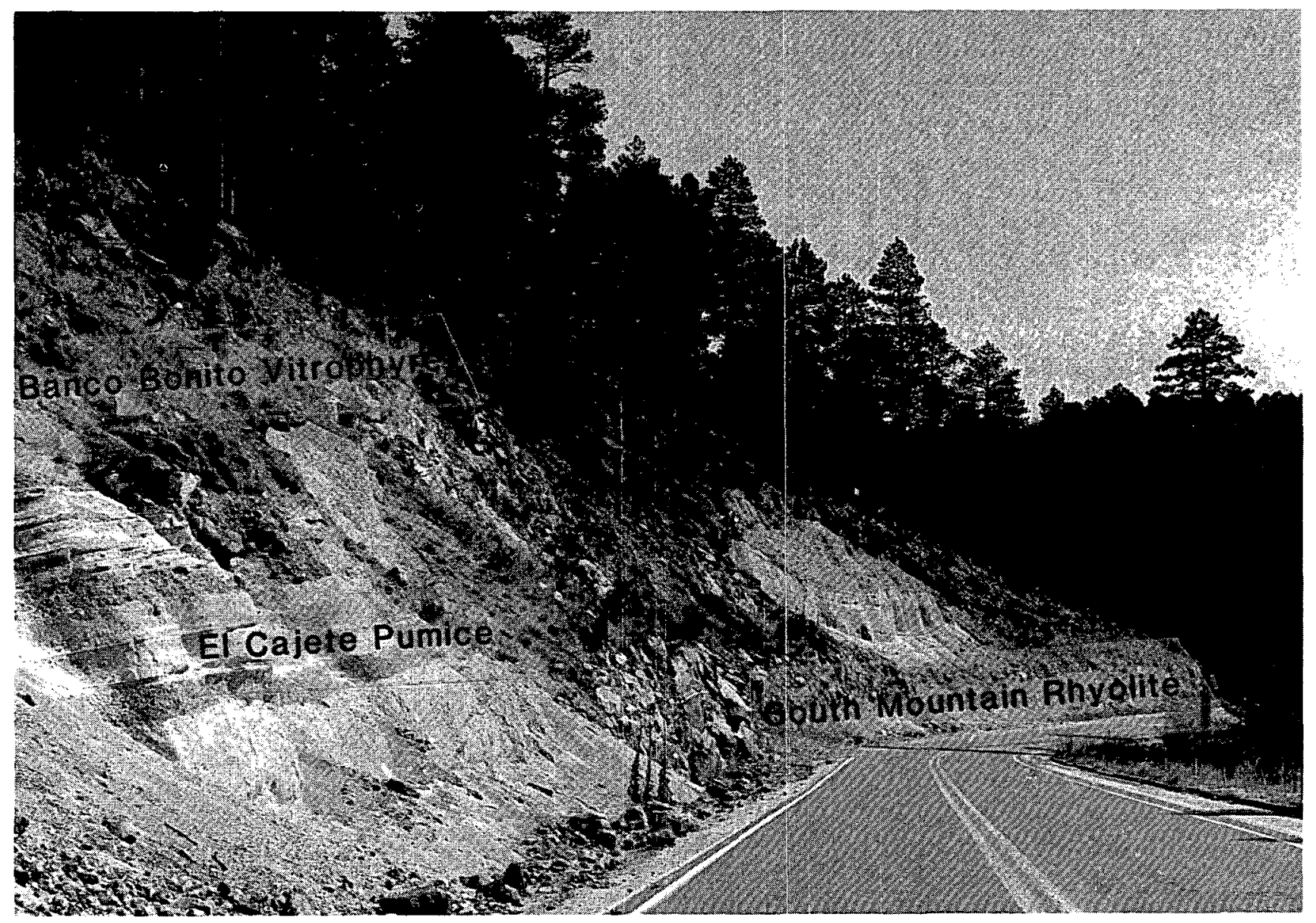

Fig. 17.

The bedded airfall and ash-flow deposits of El Cajete Rhyolite overlie erosional topography on South Mountain Rhyolite and underlie obsidian colluvium from Banco Bonito Rhyolite.

Most of the beds in this section of the El Cajete Pumice are air-fall deposits, in the lower part are two ash flows, each 2-3 m thick, with pinkish color due to high-temperature oxidation. Unlike the laterally persistent air-fall beds, they are limited in extent and fill a shallow swale, thickening in the center and thinning at their margins.

Charcoal found at the base of the uppermost fine, white ash bed in this El Cajete section gave an age of more than 42,000 years (Meyer Rubin, USGS, personal communication, 1967). On the basis of this determination and comparative morphology, the E1 Cajete Pumice and associated overlying Banco Bonito glass flow are thought to be about $0.10 \mathrm{Myr}$. The underlying South Mountain Rhyolite flow has a K-Ar age of $0.49 \mathrm{Myr}$.

Drive west on Highway 4. 


\section{1}

0.6

2.5

1.1

0.4
48.4 Road to Jemez Falls on left.

49.0 Banco Bonito obsidian flow, n0.10 Myr.

51.5 Jemez Canyon overlook on left.

52.6 Turn right on dirt road to Union 0il Co. geothermal field and Redondo Creek.

53.0 Locked gate to Union geothermal operation. Drive through gate to field trip stop about 4 miles ahead. NOTE: ACCESS BY SPECIAL PERMISSION ONLY. DO NOT TRESPASS. CONTACT UNION OIL COMPANY, SANTA ROSA, CALIFORNIA.

*STOP 10: REDONDO CREEK GRABEN; BACA \#12 WELL PAD

Redondo Creek follows the medial graben inside the resurgent dome of Valles Caldera. Redondo Peak is on the east side of the canyon while Redondo Border is on the west side. A thin cliff of Redondo Creek rhyolite erupted after formation of Valles Caldera appears above us to our west. Several northeasttrending faults help define the medial graben and are targets at depth for hydrothermal fluids. However, many of the stepped-features along the canyon walls are landslide blocks.

Union $0 i 1$ Company has drilled about 20 geothermal wells in the Redondo Creek area since 1970. Baca \#12 (Fig. 18) was drilled to Precambrian basement, reached at $3140 \mathrm{~m}$, but is not considered a producing well. Paleozoic red-beds and carbonates, Tertiary sandstone, and Miocene andesites occur above basement. Roughly $2000 \mathrm{~m}$ of silicified Bandelier Tuff overlies the older rocks, much more than estimated from surface geologic mapping.

Successful producing wells occur further up the canyon to the northeast. The deep hydrothermal system circulates in fractured ignimbrite and some underlying rock units at depths of 0.6 to $2.0 \mathrm{~km}$. Temperatures range from 260 to $330^{\circ} \mathrm{C}$ and TDS average about $7000 \mathrm{mg} / l$ in the neutral chloride fluids. Secondary mineralization to epidote grade has been reported. Union has experienced much difficulty in finding large quantities of water suitable for electrical generation. Although altered calderafill rocks and altered rhyolite occur along the Redondo Creek Canyon, very few surface hydrothermal 


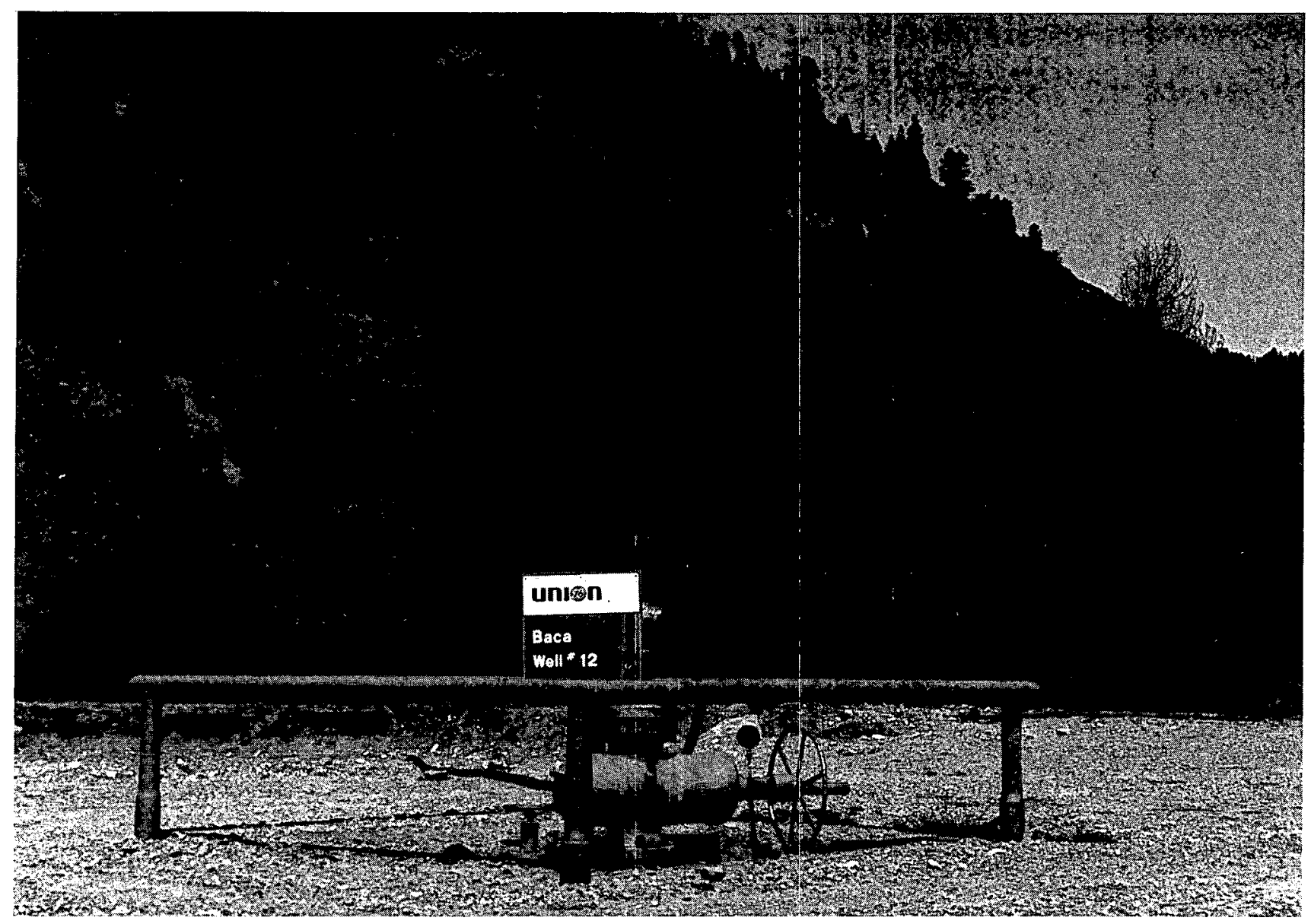

Fig. 18.

Wellhead for Baca Well \#12; Redondo Border is in background.

0.4

53.4 Highway 4, turn right (mileage from main gate).

0.3

features occur in the canyon, just a few small fumaroles and gas seeps.

Careful stratigraphic work on cuttings from several of the Baca wells (Hulen and Nielson 1982) indicate the fault blocks at depth in the reservoir are relatively flat-lying with offsets mostly down to the east. This supports the gravity data of Segar (1974) mentioned above. On the other hand, these data pose problems for the accepted model of resurgence proposed by Smith and Bailey (1968) that suggests large rotation of fault blocks above a tumescent magma body beneath. No large dikes, sills, laccoliths, or stocks of rhyolite have been recognized in any of the Baca wells.

Return to main gate and retrace route. 
53.7 Turn right on Sulphur Springs Road.

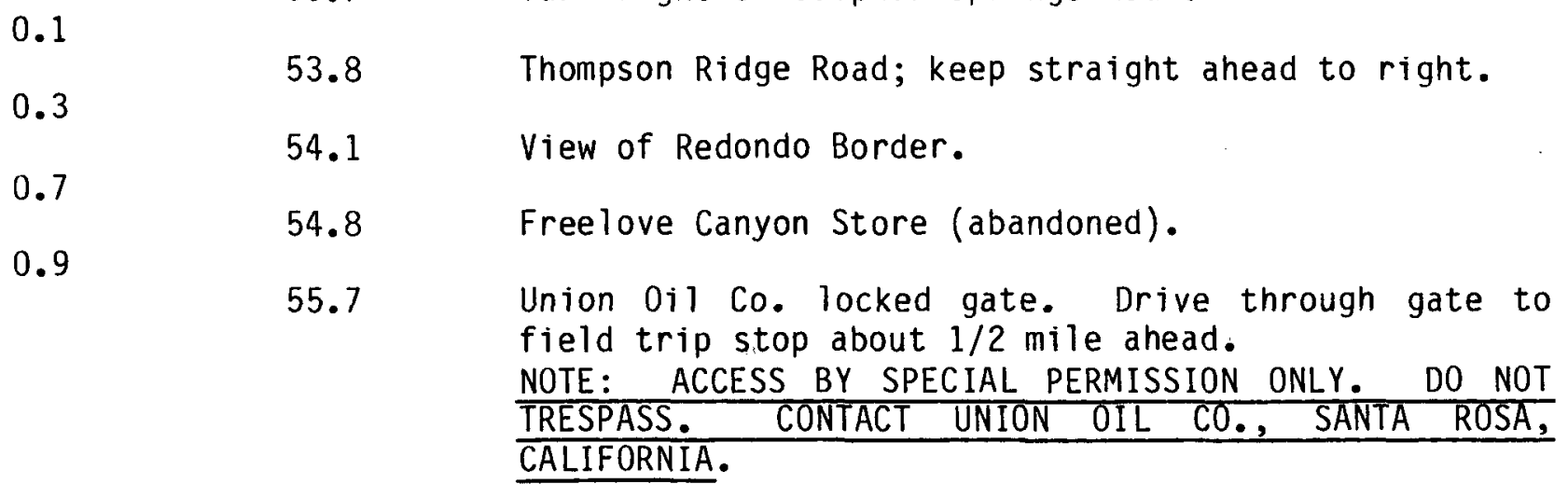

*STOP 11: SULPHUR SPRINGS

Sulphur Springs was a small resort where people bathed in waters from the springs and mudpots. The resort burned down several years ago; the other buildings have fallen to ruin (Fig. 19). The hot springs occur at the intersection of the northeasttrending Sulphur Springs Fault and several cross faults (Goff and Gardner 1980). A variety of thermal features are visible here; fumaroles, hot springs, mud pots, and gaseous cold springs (Fig. 20). Temperatures at sulphur Springs range from background to boiling, $\mathrm{pH}$ may be less than 1, and $\mathrm{SO}_{4}$ may be as high as $8,000 \mathrm{mg} / \ell$. Gases consist of mostly $98 \% \mathrm{CO}_{2}$ and $1.25 \% \mathrm{H}_{2} \mathrm{~S}$. Several types of data (empirical gas geothermometry, stable isotopes of steam and meteoric water, ${ }^{13} \mathrm{C}$ isotopes of $\mathrm{CO}_{2}$ and $\mathrm{CaCO}_{3}$ in well cuttings) suggest that the hot gases at Sulphur Springs are in equilibrium at depth with reservoirs of 200 to $300^{\circ} \mathrm{C}$. Is there a vapordominated geothermal system beneath Sulphur Springs? If so, it is probably very small.

2.0

Return to gate and retrace route.

57.7 Highway 4; turn right (south, mileage from last gate).

0.2

57.9 Small fault (red gouge zone) in rhyolite; fragments of Permian sandstone can be found in the gouge.

0.6

58.5 Junction Highway 126 and Highway 4 at La Cueva. Turn right (west) on Highway 126. Battleship Rock Tuff, a small volume ash-flow tuff, is on right.

1.5

0.5

60.0 San Antonio Campground on left.

60.5 We ascend the west wall of Valles Caldera here; orange red-beds of Permian Abo Formation on left. 


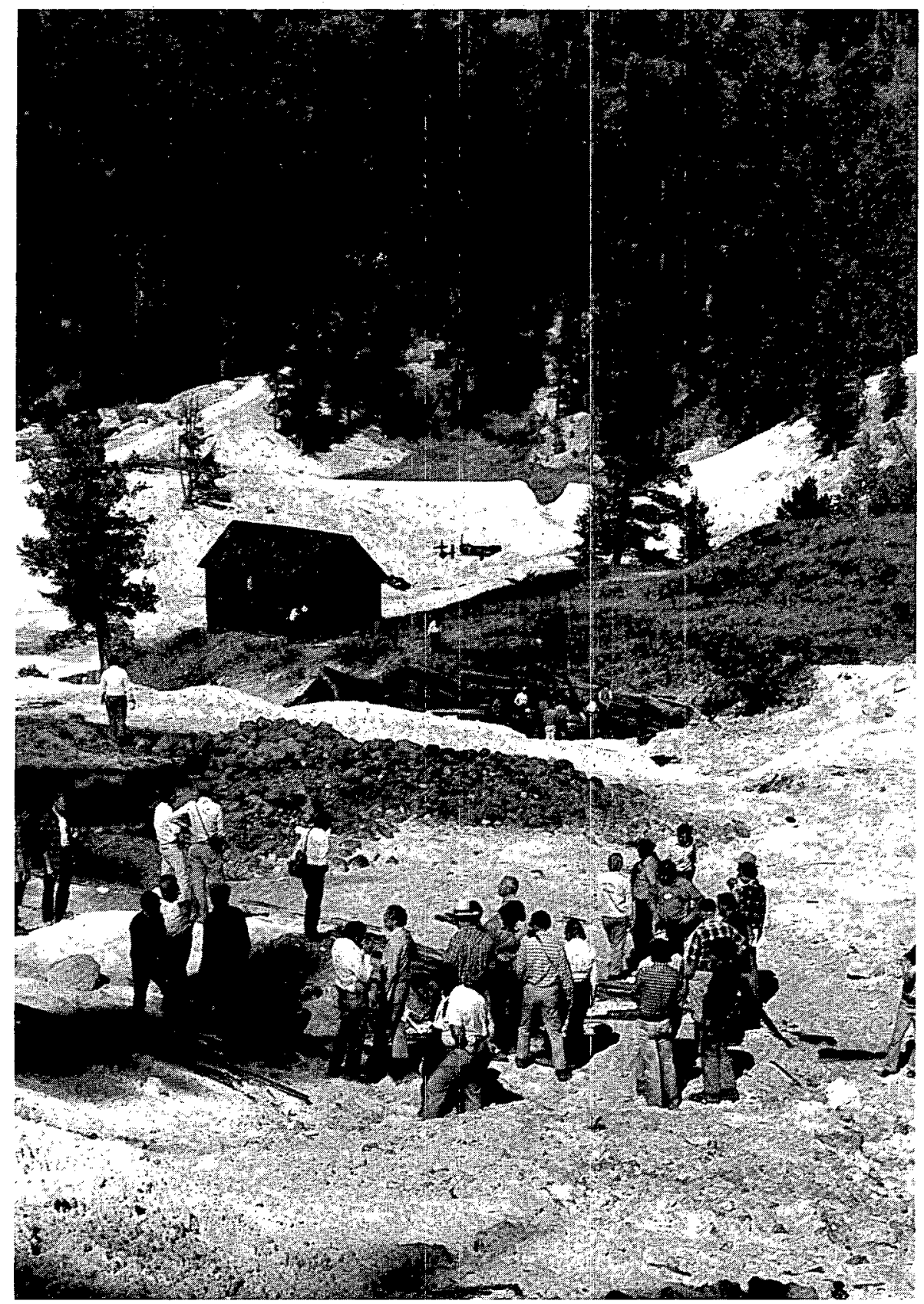

Fig. 19.

Panoramic view looking northwest into Sulphur Springs towards abandoned Men's Bathhouse. Crowd in foreground is standing over Women's Bathhouse spring, which generally is $590^{\circ} \mathrm{C}$. Acid water has created advanced argillic alterations in rhyolitic host rocks. 


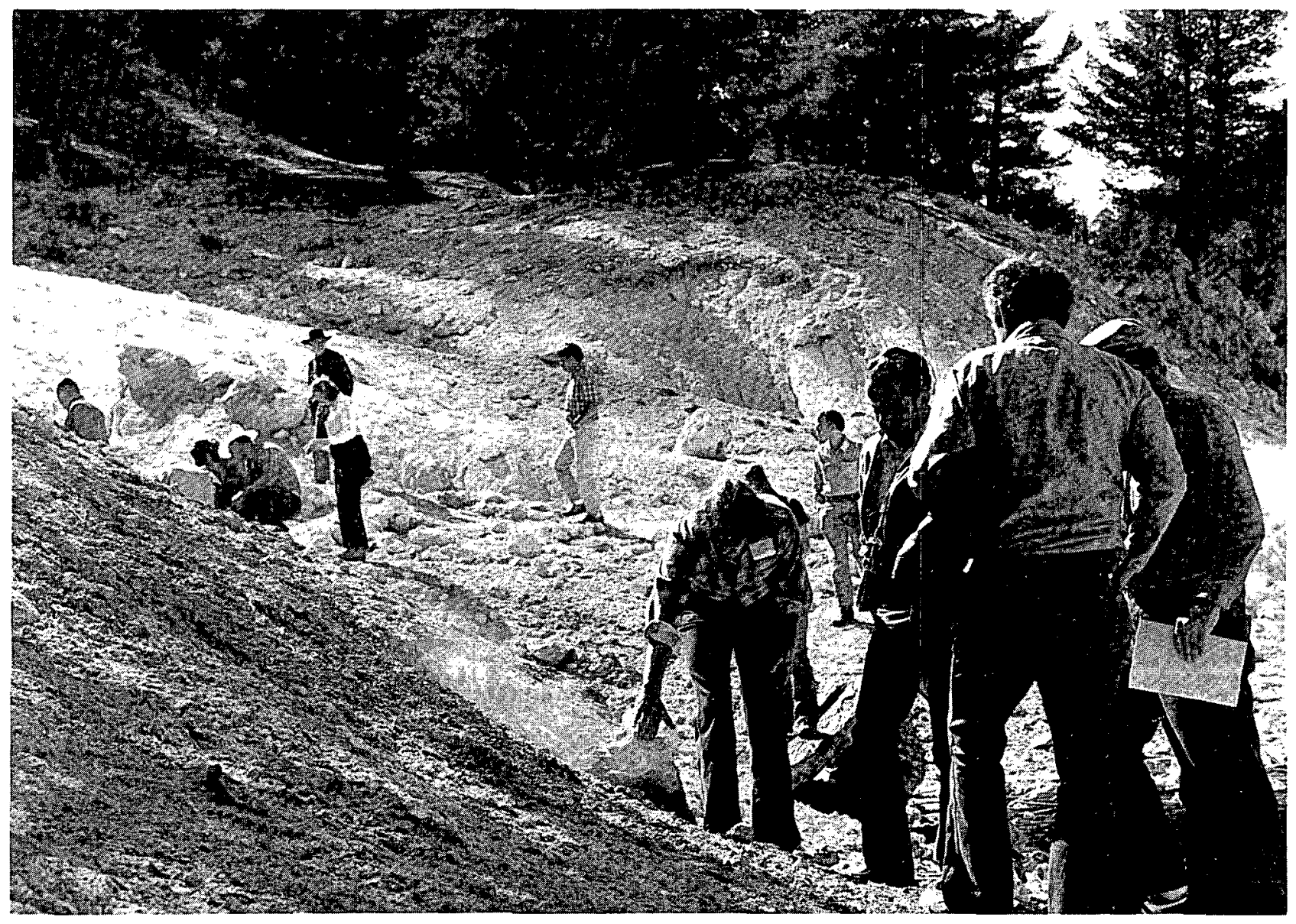

Fig. 20 .

Main fumarole area of Sulphur Springs just west of Men's Bathhouse (to left of photo). Steam issues from hydrothermally altered landslide deposit. Long needles of sulfur sublime around the mouths of fumaroles.

1.3

0.2

61.8

Abiquiu Formation ( $\backsim 25$ Myr) on right.

0.2

62.0

62.2

Paliza Canyon Andesite on right.

Turn right onto road 376 (San Antonio Hot Spring $\backsim 8$ $\mathrm{km})$. For the next $7 \mathrm{~km}$, you will pass a variety of outcrops of precaldera volcanics underlying the Upper Bandelier Tuff.

3.9

66.1

Outcrops of Permian red-beds, Abo Formation.

0.9

67.0

Turn right towards San Antonio Creek and park in turnout on left side of bridge. Cross bridge and follow road to outflow of San Antonio Hot Spring cascading downhill. Walk uphill to source of water. 
STOP 12: SAN ANTONIO HOT SPRING

NOTE: DO NOT SWIM IN SPRING; $\$ 25$ FINE BY FOREST SERVICE WILL RESULT! CONTACT JEMEZ SPRINGS RANGER STATION.

(DO NOT STOP HERE IF YOU ARE ON A ONE-DAY TRIP.)

San Antonio Hot Spring (Fig. 21) is one of several dilute hot springs that issue from the western ring-fracture zone of Valles Caldera. Isotopically, the waters are meteoric (Fig. 22, symbol tm) and they contain extremely low concentrations of $L i$ and $B$ which are often enriched in high-temperature geothermal fluids. Tritium concentrations are roughly 5 T.U. (F. Vuataz and F. Goff, Los Alamos, unpub. data) suggesting that the spring waters have a residence time underground of more than 20 years. Water issues from fractured San Antonio Mountain Rhyolite $(0.5 \mathrm{Myr})$, a moat rhyolite of the western caldera. The rhyolite resembles South Mountain Rhyolite (seen in our earlier stops).

If you gaze west across San Antonio Canyon toward the caldera wall, you can see the Lower Bandelier Tuff overlying red stratified sandstones and shales of the Permian Abo Formation. This unit is the uppermost Paleozoic formation in the immediate vicinity of the caldera. As much as $400 \mathrm{~m}$ of Abo has been penetrated by some geothermal wells to the southeast. Because it is well cemented and lithified by eons of diagenesis, the $A b o$ is fairly impermeable, thus, shallow ground waters are perched above the Abo all over the region.

Return to car, retrace route back to Highway 126 .

4.9

0.2

0.3

0.1
71.9 Highway 126, turn right.

72.1 Bandelier Tuff on right.

72.4 Turn left on side road in bend of Highway 126 .

72.5 Park vehicle and walk east toward, but not over, the cliff.

\section{*STOP 13: WEST CALDERA OVERLOOK}

Caldera overlook elevation $2615 \mathrm{~m}$. The high domical mountain due east is Redondo Péak, elevation $3460 \mathrm{~m}$, summit of the resurgent structural dome occupying the center of the Valles Caldera (Fig. 23). The nearer and lower irregularly crested ridge to the left of Redondo Peak is Redondo Border, which forms the western half of the resurgent dome. The valley 


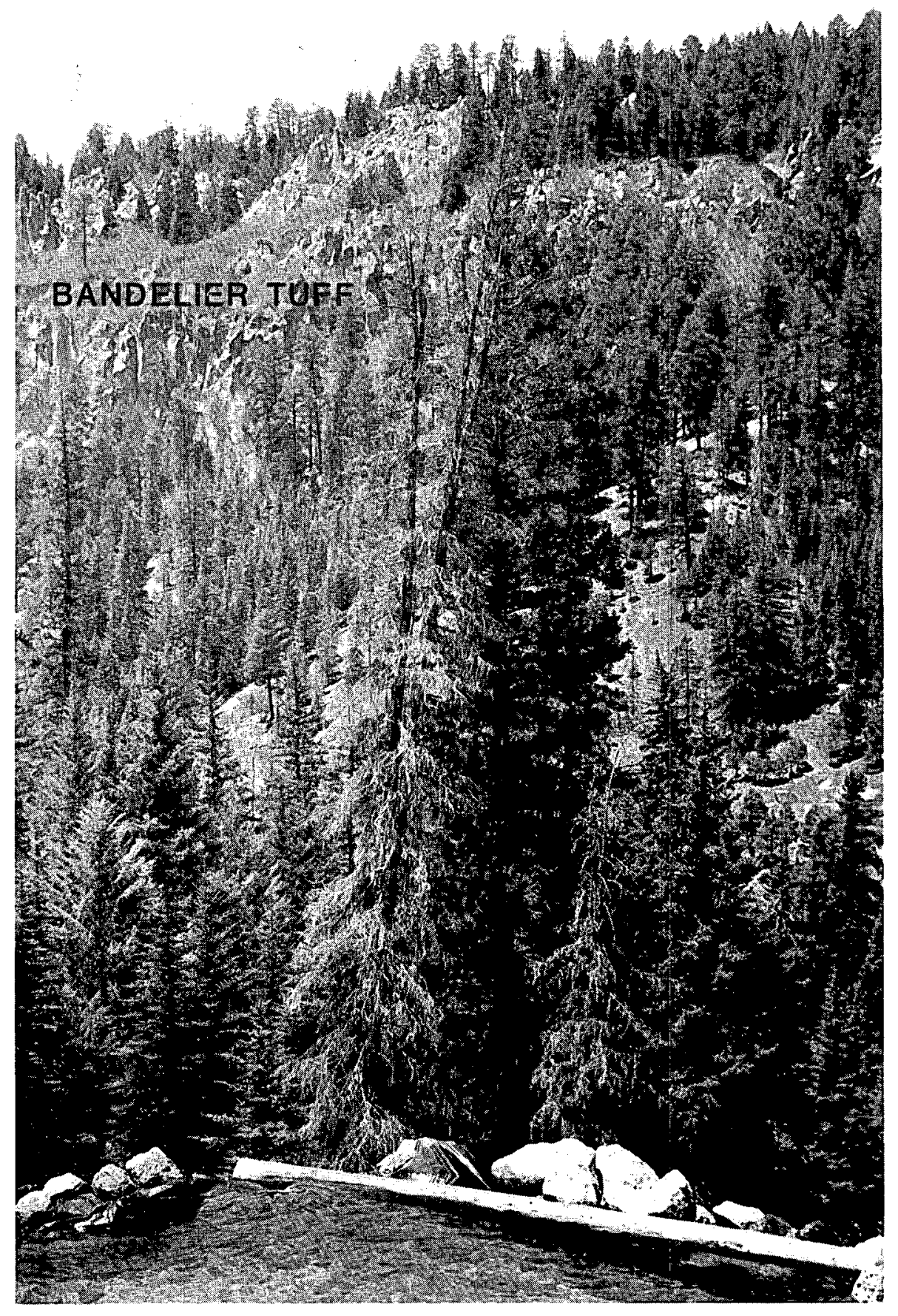

Fig. 21 .

View west from San Antonio hot spring (bottom of photo) toward caldera wall composed of Lower Bandelier Tuff. 

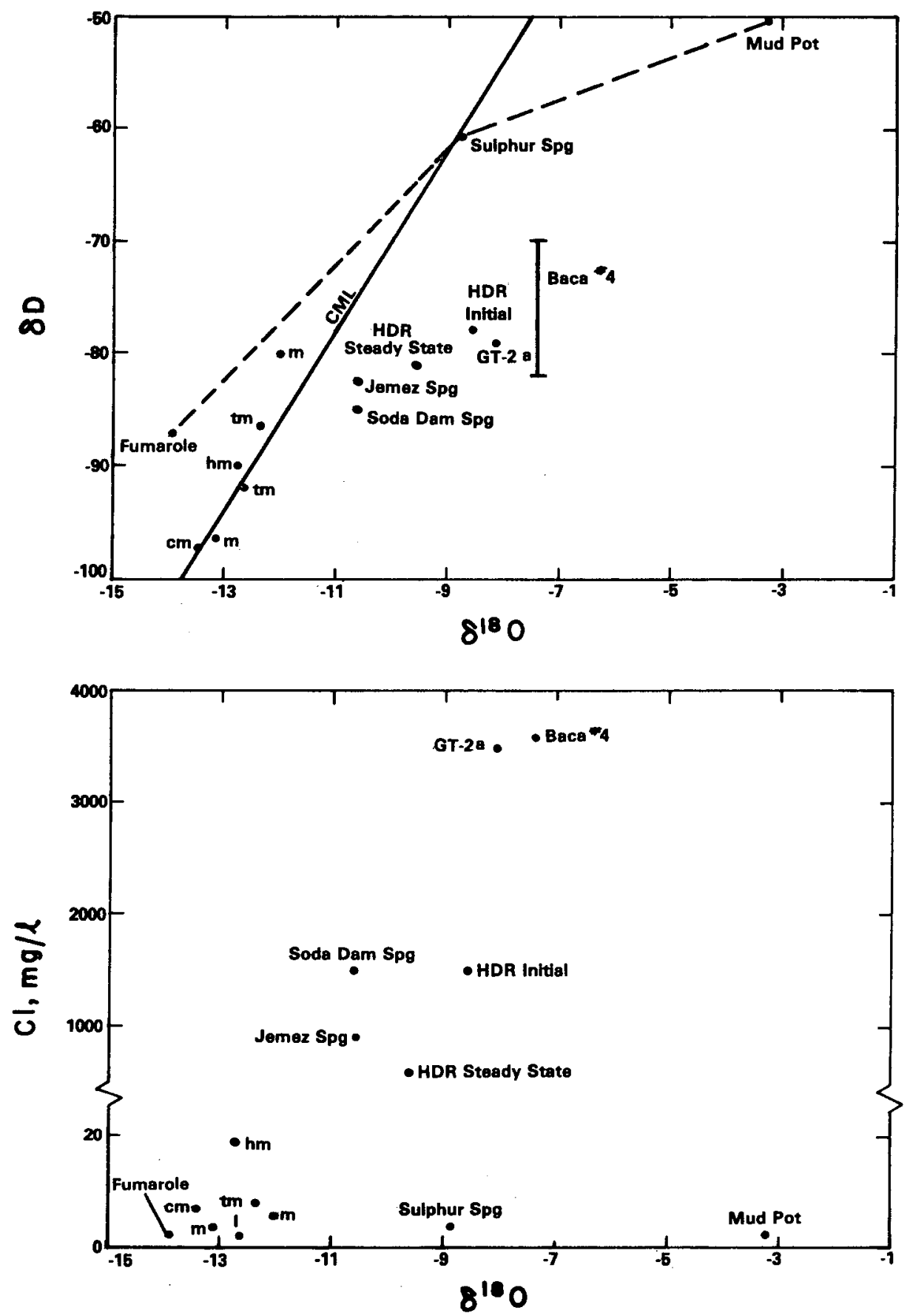

Plots of ${ }^{18} 0$ versus $D$ and ${ }^{18} 0$ versus $C l$ showing the unique isotopic and chemical character of different thermal waters in the Valles Caldera area. Symbols: Fumarole, Acid Spring, and Mud Pot from Sulphur Springs showing evaporation trend; $\mathrm{cm}$ is carbonated meteoric water from gas seep near Sulphur Springs; Baca \#4 is water from deep geothermal system; Soda Dam and Jemez Springs are deep geothermal derivatives; $\mathrm{tm}$ is thermal meteoric water from hot springs in ring-fracture zone; $m$ is cold meteoric water; GT-2 is thermal water in limestone at Fenton Hill; hm, HDR initial, and HDR steady state are make-up fluids, initial pore water, and steady state produced fluid from Fenton Hill HDR we11; figure modified from Goff and Grigsby (1982). 


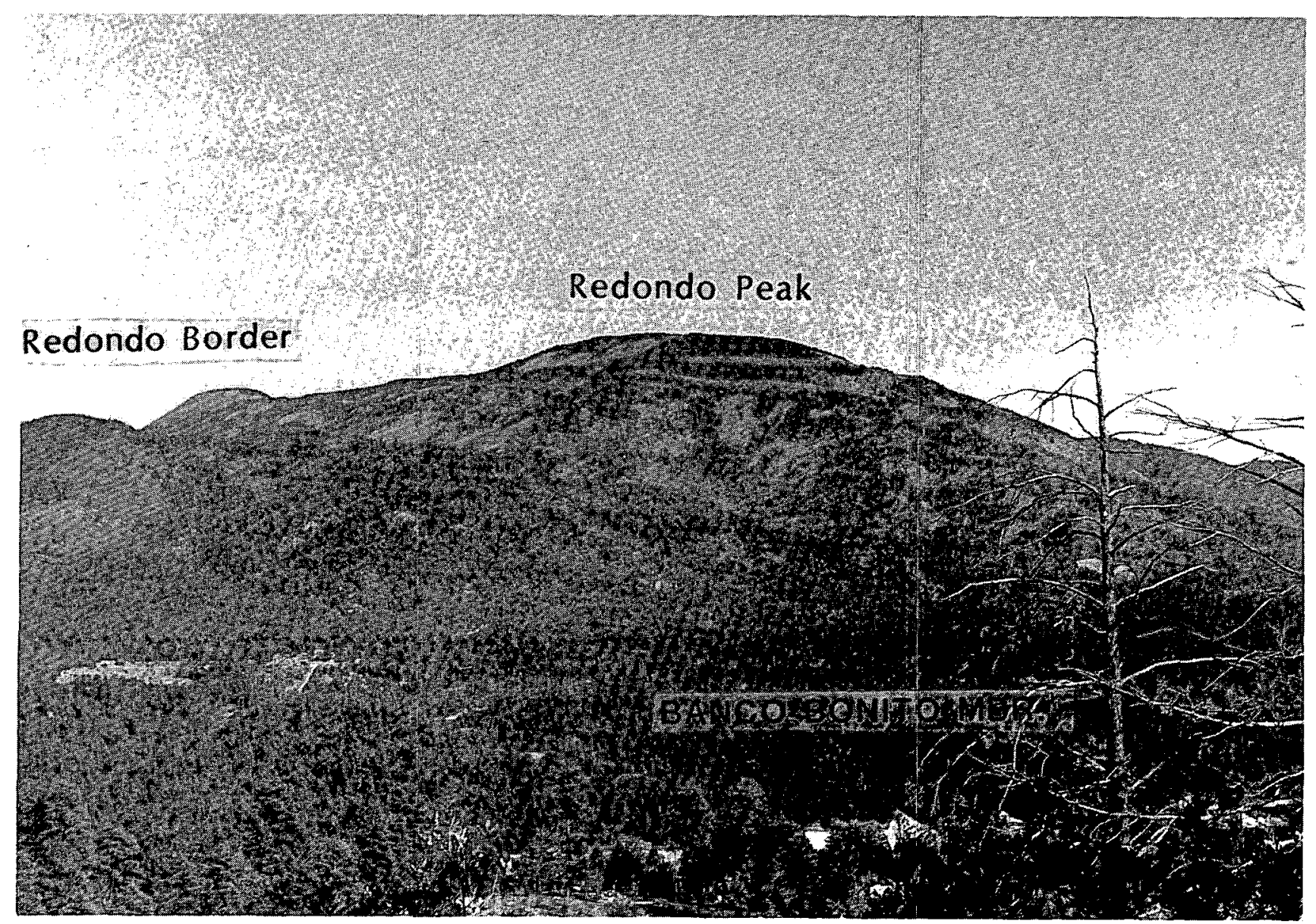

Fig. 23.

View looking east toward Redondo Peak and Redondo Border on left. The linear valley separating these two peaks is the medial graben of the resurgent dome.

between the two is a northeast-trending medial graben separating the two halves of the dome. Except for local, thin patches of elevated caldera fill (sediments and breccias), the dome is underlain by densely welded Bandelier Tuff, which has been uplifted $1000 \mathrm{~m}$ above the caldera rim and possibly as much as $1500 \mathrm{~m}$ above its postcollapse position within the caldera. The tuff on Redondo Peak is tilted generally south to southeast; the tuff on Redondo Border, generally west to northwest. The uplift of Redondo Peak occurred within 100,000 years after caldera collapse as a result of magma uprise (however, read paragraphs on subsurface structure under stops 7 and 10). This renewed upwelling may have been related to isostatic readjustments within the subcauldron magma column. These readjustments were possibly caused by the loss 
of mass accompanying eruption of the $300 \mathrm{~km}^{3}$ of magma represented by the Tshirege Member of the Bandelier Tuff (Bailey 1976).

To the northeast in the middle distance are San Antonio Mountain and Cerro Seco, two postresurgent rhyolite domes in the northwest caldera moat, 0.54 and $0.73 \mathrm{Myr}$, respectively. They are two of twelve ring domes that form the Valle Grande Member of the Valles Rhyolite. On the distant skyline to the northeast is Cerro de la Garita (on the northern rim of the caldera), formed of quartz latite of the Tschicoma Formation.

On the skyline to the southeast is the ragged crest of Los Griegos (on the south rim of the caldera), formed mainly of andesites of the Paliza Canyon Formation. In the foreground to the east-southeast is the west moat of the caldera. The southern part of this moat is occupied by the $0.1($ ?) -Myr glass flow of the Banco Bonito Member of the valles Rhyolite, and the central and northern parts are underlain by older rhyolite flow breccias of the Redondo Creek Member.

0.1

72.6 Turn left on Highway 126.

73.1 Turn left on road to Fenton Hill HDR site and immediately stop.

*STOP 14: FENTON HILL HOT DRY ROCK SITE

Fenton $\mathrm{Hill}$ is the location of the first HDR demonstration project designed and constructed by Los Alamos National Laboratory. In the HDR concept, two wells are drilled into hot impermeable formations and connected by manmade fractures. Cold surface water is pumped down one well where it is heated by the hot rocks adjacent to the fracture and removed up the other well. A heat exchanger or turbine is used to extract the heat or energy from this circulation system, after which the water is pumped back down the first well for another cycle. The first (or research) system (Fig. 24) was drilled to depths of about $3 \mathrm{~km}$ where the ambient temperature is $195^{\circ} \mathrm{C}$. This system demonstrates technical feasibility. The second engineering system is designed to show commercial feasibility. Two wellbores have already been drilled to $4.5 \mathrm{~km}$ and a maximum temperature of $325^{\circ} \mathrm{C}$. When these bores are connected with 3 to 5 fractures, it is anticipated that the deeper loop will generate up to 20 megawatts thermal energy. 


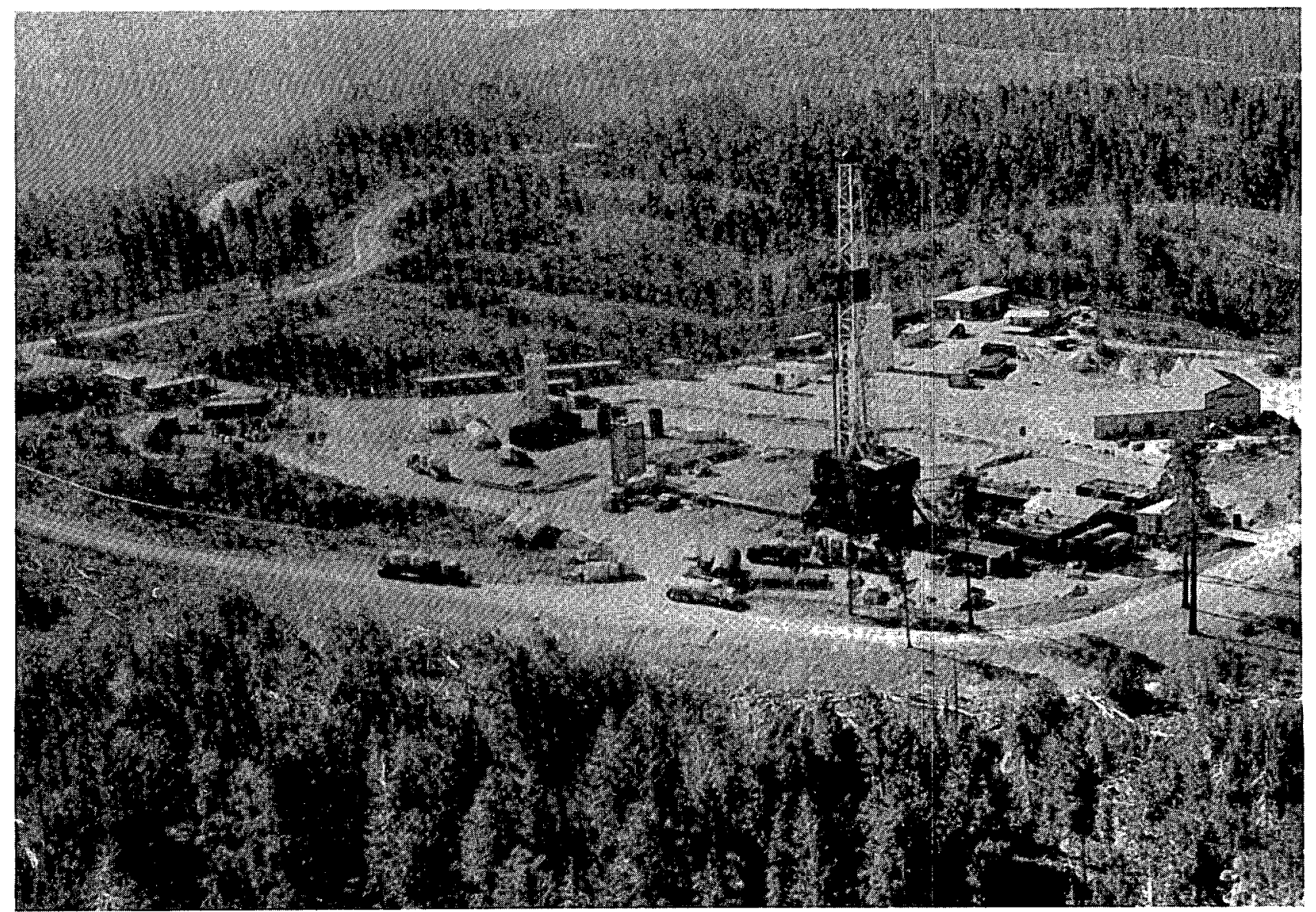

Fig. 24 .

Airplane view of Fenton Hill HDR site looking east into the southwestern moat zone of Valles Caldera.

The location of the Fenton $\mathrm{Hill}$ site on the west flank of Valles Caldera is virtually ideal because the depth to Precambrian basement is only $\backsim 800 \mathrm{~m}$, the thermal gradient and heat flow are very high $\left(>60^{\circ} \mathrm{C} / \mathrm{km}\right.$ and $3.75 \mathrm{HFU}$ respectively), and complicated structure due to caldera collapse is avoided. The location of HDR systems is more flexible than conventional hydrothermal systems because natural hot waters and their (often) scenic locations can also be avoided. For example, Fenton Hill is located on an old forest fire burn adjacent to an existing road and power line. For more details on the HDR concept, design, engineering, drilling, and U.S. exploration, see Heiken and Goff (1983) and Laughlin (1981). For a tour of the HDR facilities phone (505)667-7900. 
Retrace route back to Junction of Highway 126 and Highway 4.

77.9 Junction Highway 126 and Highway 4; turn right (south).

0.6

78.5 Banco Bonito obsidian flow overlies Battleship Rock tuff on left canyon wall; Permian red-beds on right. The upper part of San Diego Canyon follows the contact of moat rhyolites and eroded caldera rim rocks.

0.8

79.3 Spence Hot Spring issues from talus across river on left; this is another dilute meteoric not spring -. good for bathing.

0.6

79.9 First outcrop of Pennsylvanian Madera Limestone beneath Permian Abo Formation on right.

0.9

80.8 Intermittent cold mineral seep issuing from limestone on right.

0.2

0.1

81.0 Turn left to Battleship Rock picnic area.

81.1 Park in lot across bridge. (Do not go into Camp Shaver.)

STOP 15: BATTLESHIP ROCK

(DO NOT STOP HERE IF ON ONE-DAY TRIP.)

Picnic grounds are nestled at the junction of San Antonio Creek and the East Fork of the Jemez River. San Antonio Creek drains the north moat of the Valles Caldera; the East Fork drains the south moat. Battleship Rock (Fig. 25), a spectacular outcrop of columnar-jointed, rhyolite-welded tuff was formed by a series of postcaldera small-volume ash flows that issued from a vent near El Cajete Crater about 0.1 Myr(?) ago. Initially, these ash-flow deposits (the Battleship Rock Member of the Valles Rhyolite) extended a considerable distance down San Diego Canyon and filled it to a depth of about $100 \mathrm{~m}$, but subsequent erosion has removed all but the outcrops in the Battleship Rock area and one or two other small remnants down-canyon. Battleship Rock itself is the filling of a narrow vertical-walled gorge cut into Madera Limestone and Abo Formation, and the curved columnar jointing in the lower part of Battleship Rock is a consequence of cooling against the gorge walls. Subsequent erosion has removed the adjacent less resistant sedimentary rocks and has left the more resistant welded tuff standing as a 


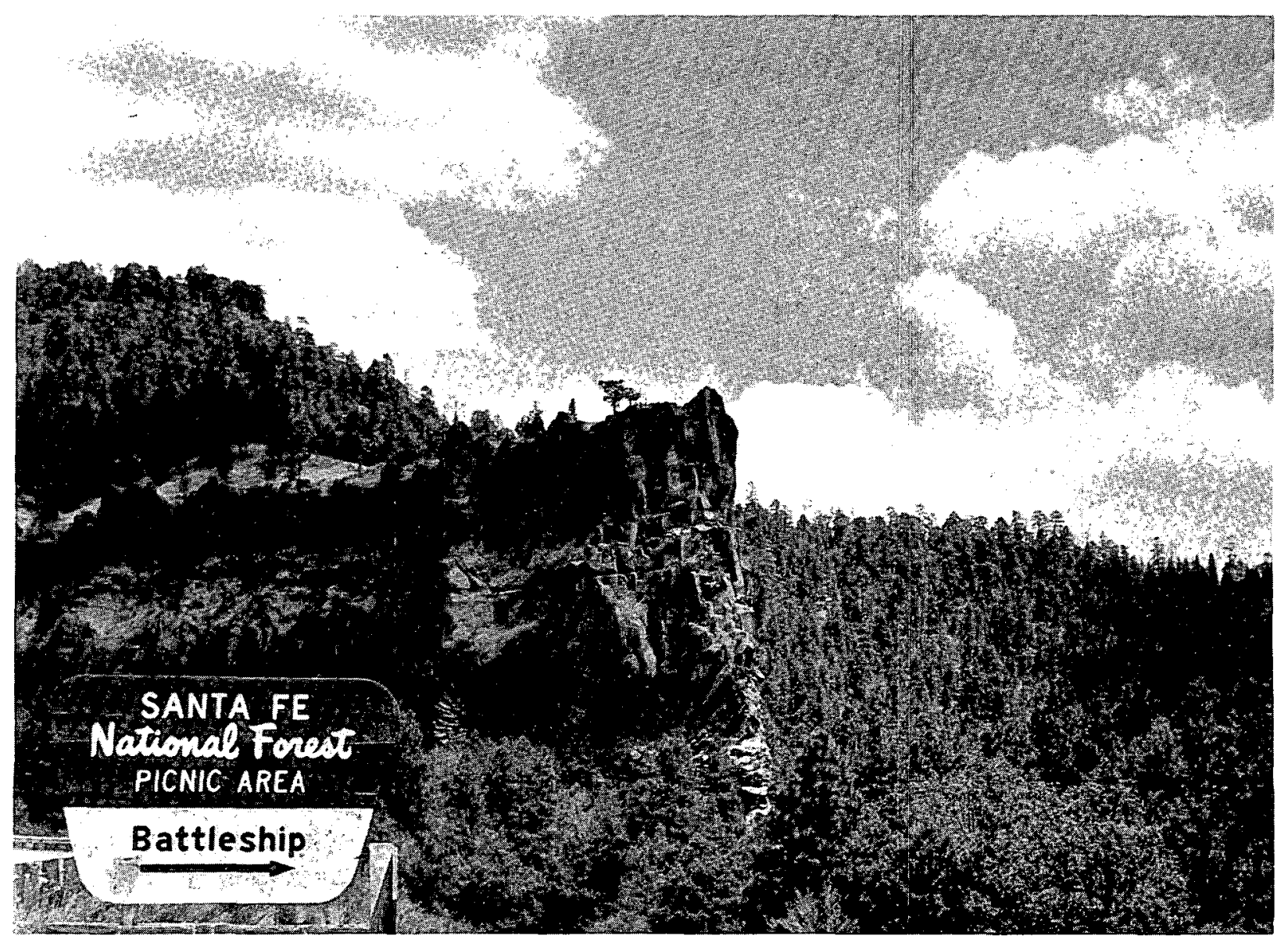

Fig. 25 .

Battleship Rock, a small-volume ash-flow tuff occupying an ancestral canyon of the Jemez River. Note radial cooling joints.

promontory - - an interesting example of inverted topography.

The tuff at Battleship Rock is about $80 \mathrm{~m}$ thick and contains two main flow units that constitute a single cooling unit (Smith 1960). The tuff is entirely vitric from bottom to top. The basal $15 \mathrm{~m}$ are composed of poorly consolidated pumiceous tuff breccia, which becomes increasingly compacted upward and grades into partly welded tuff having a minimum porosity of $15 \%$ at approximately $35 \mathrm{~m}$ above the base. The tuff becomes gradually less welded and passes again into unconsolidated pumiceous tuff breccia about $65 \mathrm{~m}$ above the base.

If you look at the contact zone between tuff and underlying rocks on the east side of Battleship Rock, note that the tuff sits on a small cliff of Pennsylvanian Madera Limestone. Note also that 
0.1
0.6

81.2

81.8

2.1

83.9

0.5 massive limestone beds are separated by thin shale partings. The limestone here is extremely fossiliferous and includes crinoids, brachiopods, and bryozoa. Madera limestone contains both hot and cold mineralized aquifers throughout the southwestern flank of Valles Caldera and has been penetrated inside the caldera by at least four geothermal wells.

Return to Highway 4.

Turn left (south) on Highway 4.

Fumarole of $\mathrm{H}_{2} \mathrm{~S}$ and $\mathrm{CO}_{2}$ on left (do you smell it?) issues from a strand of the Jemez fault zone. Lower San Diego Canyon has formed along this fault zone. $\mathrm{H}_{2} \mathrm{~S}$ from fumarole is oxidized to $\mathrm{H}_{2} \mathrm{SO}_{4}$ and alters the rocks here. There is no associated hot spring.

Large blockslide in Madera Limestone on left across river.

84.4 Park in turnout on right before travertine dam on left.

*STOP 16: SODA DAM AND JEMEZ FAULT ZONE

The travertine dam across the gorge in Precambrian granite was built by carbonated thermal waters that discharge from a strand of the Jemez fault zone (Fig. 26). There are roughly 10 springs and seeps discharging in this area including one across the river to the left of the high travertine knob. About 15 years ago, water discharged along the top of the dam. Today Soda Dam is slowly falling apart.

The waters discharge at $\backsim 48^{\circ} \mathrm{C}, \mathrm{Cl}=1500 \mathrm{mg} / \ell$. The ratios of very soluble elements, $\mathrm{Na}, \mathrm{Li}, \mathrm{Cl}$, and $\mathrm{B}$ are practically identical to those from the deep fluid within Valles Caldera (Trainer 1975; Goff et a1. 1981). This and other evidence indicates the waters here are derivatives of those deep within valles. Leakage and mixing occurs southwest down various strands of the Jemez fault zone.

01 der travertine deposits crop out high above us west of Soda Dam and include river gravels with cobbles of Bandelier Tuff. The spring system has been active here for a long time while the river cut the gorge.

The Jemez fault zone is very complex in this area. The main trace trends northeast across the highway. 


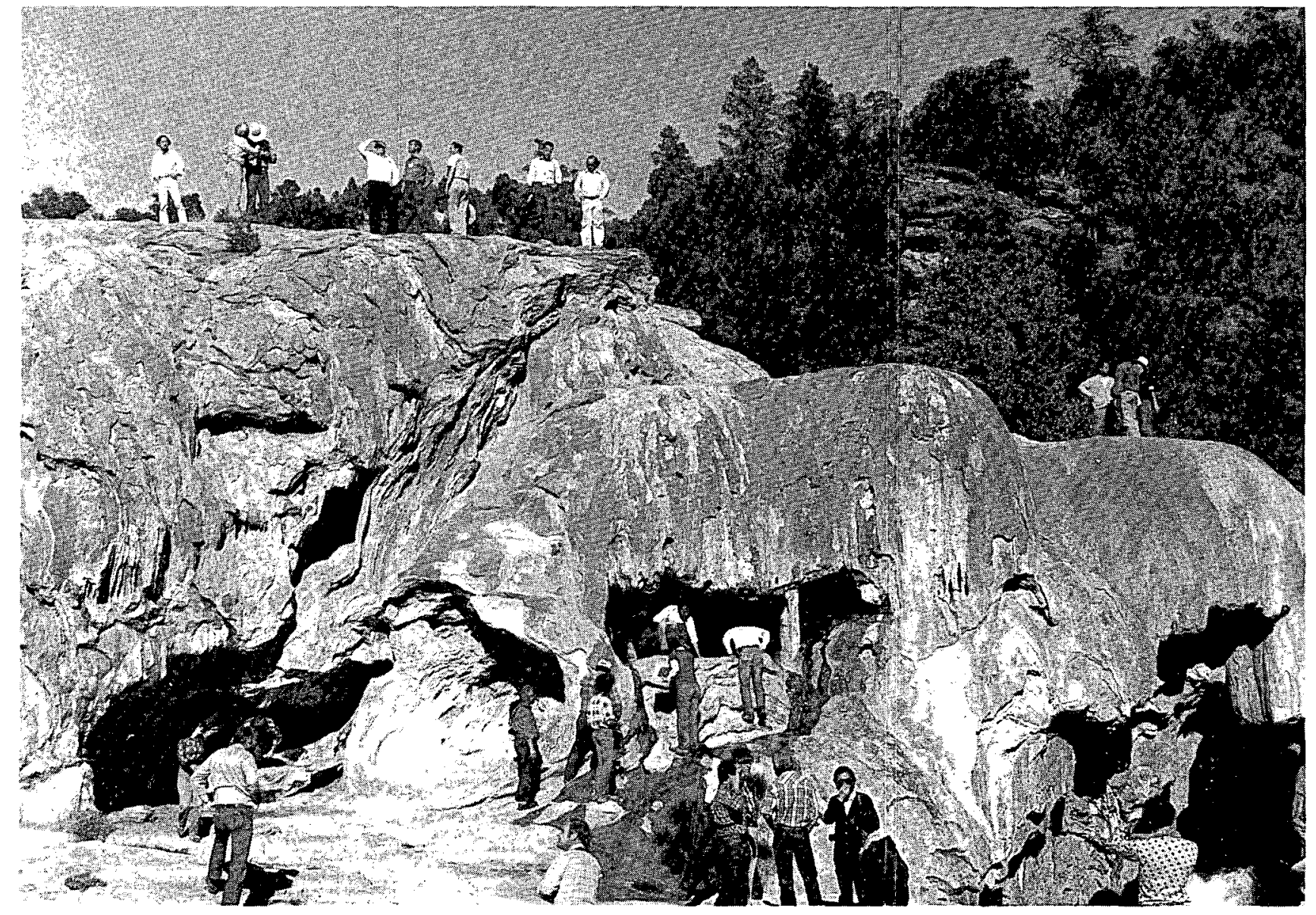

Fig. 26.

Soda Dam, a hot spring deposit of travertine now undercut by the Jemez River (lower right in photo). Narrow cavern in center of photo leads to Grotto Spring. Main hot spring discharges along highway to left of photo.

Generally, the displacement is down to the east about 200-250 $\mathrm{m}$ because the Jemez fault zone is the westernmost of the Rio Grande rift faults. At Soda Dam, a local horst of sheared Precambrian is uplifted and contorts Paleozoic rocks all around it. If you gaze carefully at the upper east wall of San Diego Canyon (Fig. 27), you can see a white band of Abiquiu Formation (25 Myr) overlying orange Permian shales. The Abiquiu is overlain by a sequence of volcanic units of Paliza Canyon Formation, from bottom to top, basalt flows, and andesite flows and flow-breccias. The Bandelier Tuff is thin, only the Tshirege Member covers the older volcanics.

0.5

Continue south on Highway 4.

84.9 Jemez Ranger Station on left; a pair of faults bounding the east side of the Precambrian horst at 


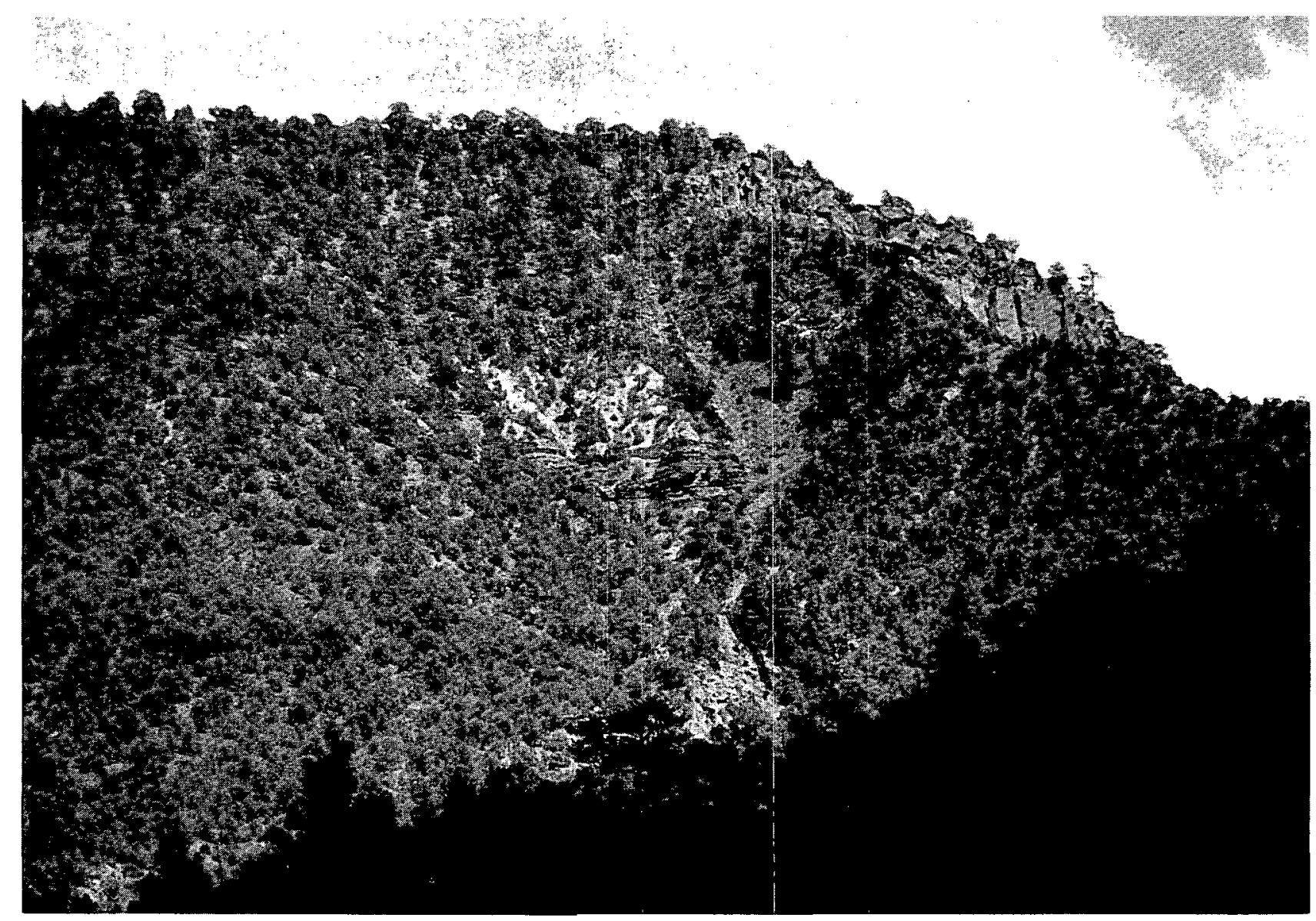

Fig. 27.

Stratigraphy of upper wall, Cañon de San Diego looking east from Soda Dam.

Soda Dam trend southwest from topographic gullies behind the ranger station.

0.5

old Spanish mission (ruins) on left.

0.5

85.4

Jemez Springs bathhouse on right.

0.1

85.9

Park in turnout before Los 0jos on left.

86.0

$\frac{\text { STOP 17: JEMEZ SPRINGS, DINNER AT LOS OJOS (OPTIONAL) }}{\text { (DO NOT STOP HERE IF ON A ONE DAY TRIP.) }}$

If you have time, a quick tour of the thermal waters near the bathhouse on the west side of the road is very interesting (Fig. 28). These waters also appear to be derived from those in the caldera; maximum temperature is $72^{\circ} \mathrm{C}, \mathrm{Cl}=900 \mathrm{mg} / \mathrm{l}$. In January 1979, the community of Jemez Springs drilled 
a well $255 \mathrm{~m}$ that bottomed in Precambrian granite. They were seeking hotter water $\left(\backsim 100^{\circ} \mathrm{C}\right)$ for use in space heating. The hottest water they found was about $72^{\circ} \mathrm{C}$ at the top of limestone (base of alluvium) at $25 \mathrm{~m}$. The hot-water resource here is probably of small size. Several other springs of various compositions and temperatures discharge in the grassy flat by the river (Fig. 29).

Los 0 jos is a small restaurant characteristic of many small New Mexico communities. Enjoy your meal.

END OF FIELD TRIP; retrace route on Highway 4 back to Los Alamos or continue southwest on Highway 4 towards Albuquerque.

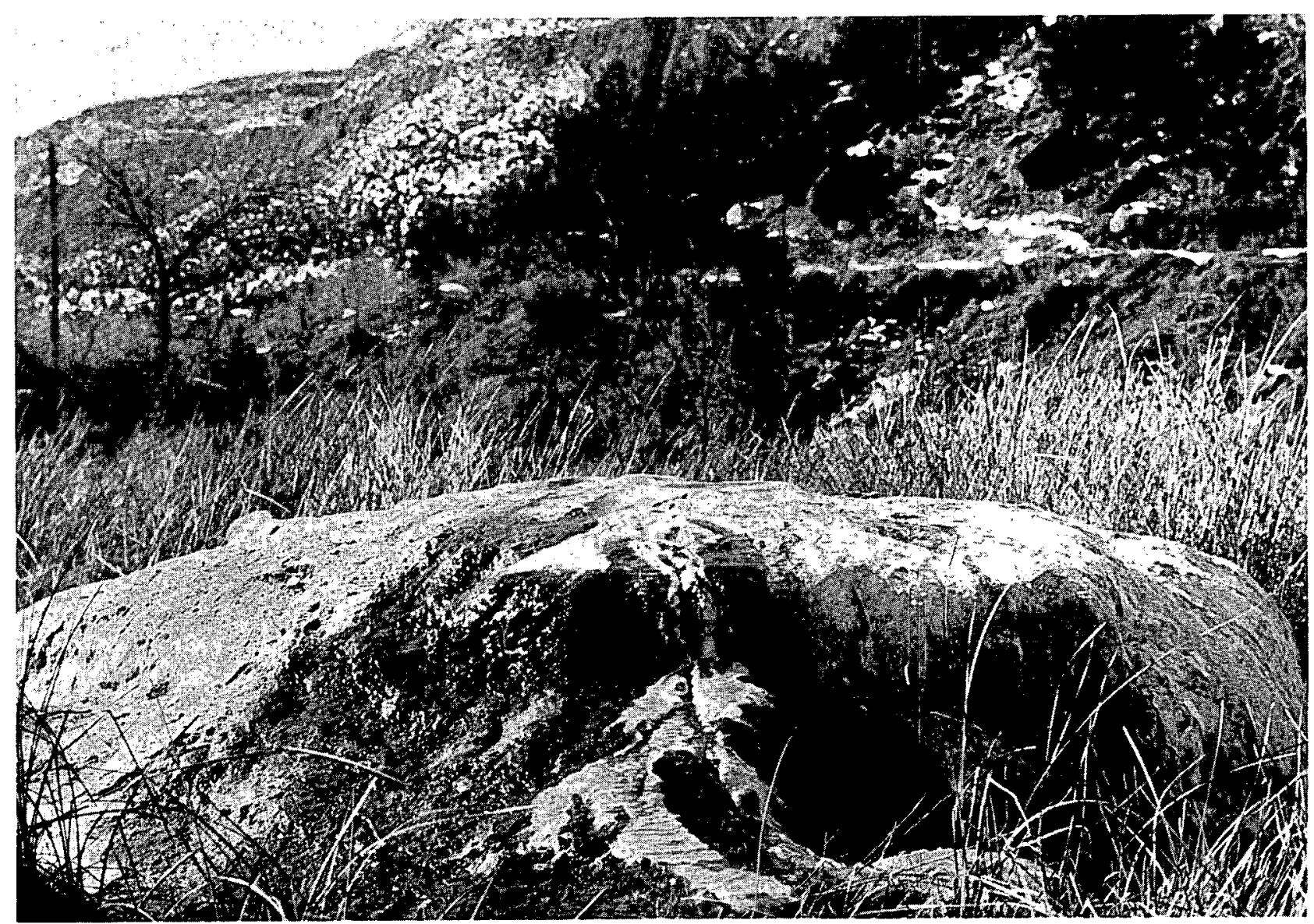

Fig. 28 .

Travertine Mound Spring $\left(72^{\circ} \mathrm{C}\right)$, the hottest hot spring outside of Valles Caldera, is reported to contain an extremely rare species of algae and discharges bicarbonated water in the reeds between the Jemez River and Bathhouse at Jemez Springs. 


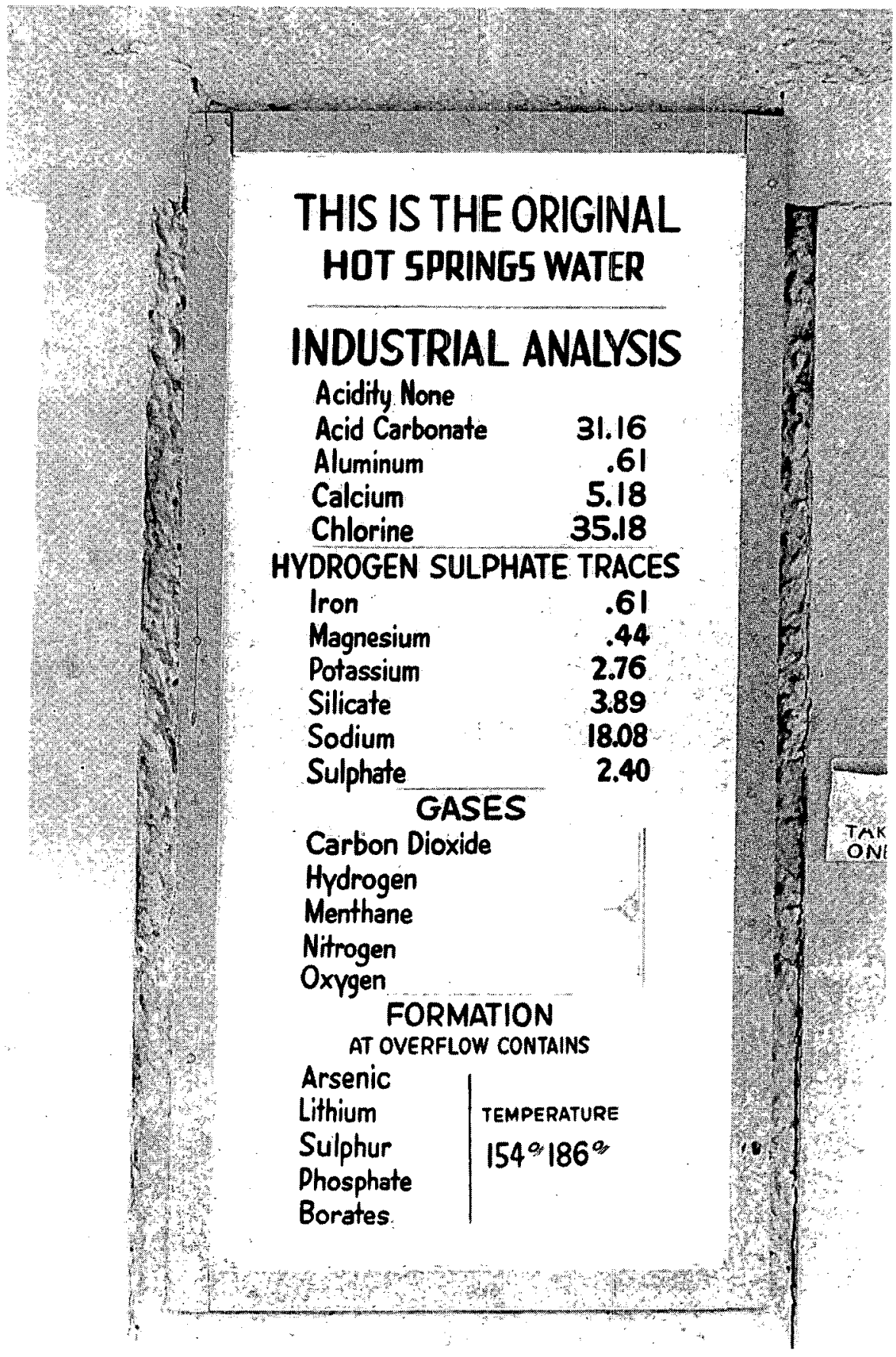

Fig. 29.

This sign is posted beside the front door of Jemez Springs Bathhouse. 


\section{SELECTED BIBLIOGRAPHY}

Bailey, R. A., "On the Mechanisms of Postsubsidence Central Doming and Volcanism in Resurgent Cauldrons," Abstr. Progr., Geol. Soc. Am. 8(5), 567 (1976).

Bailey, R. A. and R. L. Smith, "Volcanic Geology of the Jemez Mountains, New Mexico," in J. W. Hawley (Editor), "Guidebook to the Rio Grande Rift in New Mexico and Colorado," N.M. Bur. Mines Miner. Resour., Circ. 163, 184-196 (1978).

Bailey, R. A., R. L. Smith and C. S. Ross, "Stratigraphic Nomenclature of Volcanic Rocks in the Jemez Mountains, New Mexico," U.S. Geol. Surv., Bu11. 1274-P, P1-P19 (1969).

Baldridge, W. C., "Petrology and Petrogenesis of Plio-Pleistocene Basaltic Rocks from the Central Rio Grande Rift, New Mexico, and Their Relation to Rift Structure," in R. E. Riecker (Editor), "Rio Grande Rift: Tectonics and Magmatism," Am. Geophys. Union, Washington, DC, 323-354 (1979).

Budding, A. J., "Gravity Survey of the Pajarito Plateau, Los Alamos and Santa Fe Counties, New Mexico," Los Alamos Scientific Laboratory report LA-7419-MS, 15 pp. (1978).

Chapin, C. E., R. H. Chamberlin, G. R. Osburn, D. W. White and A. R. Sanford, "Exploration Framework of the Socorro Geothermal Area, New Mexico," N.M. Geo1. Soc., Spec. Pub. 7, 114-129 (1978).

Corde11, L., "Regional Geophysical Setting of the Rio Grande Rift," Geol. Soc. Am. Bu11. 89, 1073-1090 (1978).

Dalrymple, G. B., Allan Cox, R. R. Doell and C. S. Grommé, "Pliocene Geomagnetic Polarity Epochs," Earth Plan. Sci. Lett. 2, 167-173 (1967).

Doell, R. R., G. B. Dalrymple, R. L. Smith and R. A. Bailey, "Paleomagnetism, Potassium-Argon Ages, and Geology of Rhyolites and Associated Rocks of the Valles Caldera, New Mexico," Geo1. Soc. Am. Mem. 116, 211-248 (1968).

Dondanville, R. F., "Geologic Characteristics of the Valles Caldera Geothermal System, New Mexico," Trans., Geotherm. Resour. Coun. 2, 157-160 (1978).

Galusha, Ted, "The Zia Sand Formation, New Early Miocene to Medial Miocene Beds in New Mexico," American Museum Novitates No. 2271, pp. 1-12 (1966).

Galusha, Ted and J. C. Blick, "Stratigraphy of the Santa Fe Group, New Mexico," American Museum of Natural History Bul1. 144, 127 pp. (1971).

Gardner, J. N., "Tectonic and Petrologic Evolution of the Keres Group: Implications for the Development of the Jemez Volcanic Field, New Mexico," Ph.D. Dissertation, Univ. of California, Davis, California (1983, in prep.).

Goff, F., "Subsurface Structure of Valles Caldera; A Resurgent Cauldron in Northern New Mexico," Abstr. Progr., Geol. Soc. Am. 15(5), 381 (1983). 
Goff, F. E. and J. N. Gardner, "Geologic Map of the Sulphur Springs Geothermal System, Valles Caldera, New Mexico," Los Alamos National Laboratory map LA-8634-MAP, 2 sheets (1:5000 scale) (1980).

Goff, F. and C. 0. Grigsby, "Valles Caldera Geothermal Systems, New Mexico, USA," J. Hydrology 56, 119-136 (1982).

Goff, F. E., C. 0. Grigsby, A. Kron, D. Counce and P. Trujillo, "Geology, Water Geochemistry, and Geothermal Potential of the Jemez Springs Area, Cañon de San Diego, New Mexico," J. Volcano1. Geotherm. Res. 10, 227-244 (1981).

Griggs, R. L., "Geology and Ground-water Resources of the Los Alamos Area, New Mexico," U.S. Geol. Surv. Water-Supply Paper 1753, 107 pp. (1964).

Heiken, G. and F. Goff, "Hot Dry Rock Geothermal Energy in the Jemez Volcanic Field, New Mexico," J. Volcanol. Geotherm. Res. 15, 223-246 (1983).

Hermance, J. F., "Toward Assessing the Geothermal Potential of the Jemez Mountains Volcanic Complex; A Telluric-Magnetotelluric Survey," Los Alamos Scientific Laboratory report LA-7656-MS (1979).

Hulen, J. B. and D. L. Nielson, "Stratigraphic Permeability in the Baca Geothermal System, Redondo Creek Area, Valles Caldera, New Mexico," Trans., Geotherm. Resour. Coun. 6 , 27-30 (1982).

Kelley, V. C., E. H. Baltz and R. A. Bailey, "Road Log: Jemez Mountains and Vicinity," N.M. Geol. Soc. Guideb., 12th Field Conf., pp. 47-62 (1961).

Laughlin, A. W., "The Geothermal System of the Jemez Mountains, New Mexico and its Exploration," in L. Rybach and L. P. J. Muffler (Editors), Geothermal Systems - Principa $\sqrt{s}$ and Case Histories, John Wiley and Sons, New York, 1981), pp. 295-320.

Laughlin, A. W., D. G. Brookins, and J. D. Causey, "Late Cenozoic Basalts from the Bandera Lava Field, Valencia County, New Mexico," Geol. Soc. Am. Bull. 83, 1143-1551 (1972).

Laughlin, A. W., D. G. Brookins and P. E. Damon, "Late-Cenozoic Basaltic Volcanism Along the Jemez Zone of New Mexico and Arizona," Abstr. Progr., Geol. SoC. Am. $\underline{8}, 598$ (1976).

Laughlin, A. W., M. J. Aldrich, Jr., M. E. Ander, G. H. Heiken, and D. T. Vaniman, "Tectonic Setting and History of Late-Cenozoic Volcanism in West-central New Mexico," N.M. Geol. Soic. Guidebook 33, 279-284 (1982).

Laughl in, A. W., A. C. Eddy, R. Laney, and M. J. Aldrich, Jr., "Geology of the Fenton Hi11, New Mexico, Hot Dry Rock Site," J. Volcanol. Geotherm. Res. 15, 21-40 (1983).

Mayo, E. B., "Lineament Tectonics and Some Ore Districts of the Southwest," AIME Trans., 1169-1175 (1958). 
01 sen, K. H., L. W. Braile, J. N. Stewart, and C. R. Daudt, "Seismic Search for Evidence of Magma Beneath the Jemez Mountains in the Northern Rio Grande Rift," Abstr. Progr., Geol. Soc. Am. 15(5), 381 (1983).

Rieter, M., C. Weidman, C. L. Edwards, and H. Hartman, "Subsurface Temperature Data in Jemez Mountains, New Mexico," N.M. Bur. Miner. Resour., Circ. 151, pp. $1-15$ (1976).

Riecker, R. (editor), "Rio Grande Rift: Tectonics and Magmatism," Am. Geophys. Union, Washington, DC, 438 pp. (1979).

Riecker, R., "Plate Tectonics - Where the Action Is," Los Alamos Science (Summer 1980), pp. 141-145.

Ross, C. S., R. L. Smith and R. A. Bailey, "Outline of the Geology of the Jemez Mountains, New Mexico," N.M. Geol. Soc. Guideb., 12th Field Conf., pp. 139-143 (1961).

Segar, R. L., "Qualitative Gravity Interpretation, Valles Caldera Area, Sandoval and Rio Arriba Counties, New Mexico," consulting report to Union 0 il Company, Santa Rosa, California, 10 pp. with maps (1974).

Smith, H. T. U., "Tertiary Geology of the Abiquiu Quadrangle, New Mexico," J. Geology 46(7), 933-965 (1938).

Smith, R. L., "Ash Flows," Geol. Soc. Am. Bu11. 71, 795-842 (1960).

Smith, R. L. and R. A. Bailey, "The Bandelier Tuff, A Study of Ash-Flow Eruption Cycles from Zoned Magma Chambers," Bul1. Volcan. 29, 83-104 (1966).

Smith, R. L. and R. A. Bailey, "Resurgent Cauldrons," Geo1. Soc. Am. Mem. 116, 613-662 (1968).

Smith, R. L., R. A. Bailey and C. S. Ross, "Structural Evolution of the Valles Caldera, New Mexico, and Its Bearing on the Emplacement of Ring Dikes," U.S. Geol. Surv. Prof. Paper 424-D, D145-D149 (1961).

Smith, R. L., R. A. Bailey and C. S. Ross, "Geologic Map of the Jemez Mountains, New Mexico," U.S. Geol. Surv. Misc. Geol. Inv. Map I-571, scale $1: 125,000(1970)$.

Swanberg, C. A., "Heat Flow at the Valles Caldera, New Mexico," Abstr. Progr., Geol. Soc. Am. 15(5), 381 (1983).

Trainer, F. W., "Mixing of Thermal and Non-thermal Waters in the Margin of the Rio Grande Rift, Jemez Mountains, New Mexico," N.M. Geol. Soc. Guideb., 26th Field Conf., Las Cruces County, pp. 213-218 (1975).

Trainer, F. W., "Geohydrologic Data from the Jemez Mountains and Vicinity, North-Centrai New Mexico," U.S. Geo1. Surv. Water Resources Invest. 77-131, 146 pp. (1978). 
Williston, NcNeil and Associates, "A Time-Domain Survey of the Los Alamos Region, New Mexico," Los Alamos Scientific Laboratory report LA-7657-MS, 32 pp. (1979).

Wood, G. H. and S. A. Northrop, "Geology of Nacimiento Mountain, San Pedro Mountain, and Adjacent Plateaus in Parts of Sandoval and Rio Arriba Counties, New Mexico," U.S. Geol. Surv., $0 i 1$ and Gas Inv. Prelim. Map 57, scale $1: 95,040(1946)$.

Woodward, L. A. and R. L. Ruetschilling, "Geology of San Ysidro Quadrangle, New Mexico," N.M. Bur. Mines Miner. Resour., Geol. Map 37, scale 1:24,000 (1975). 
NOTES

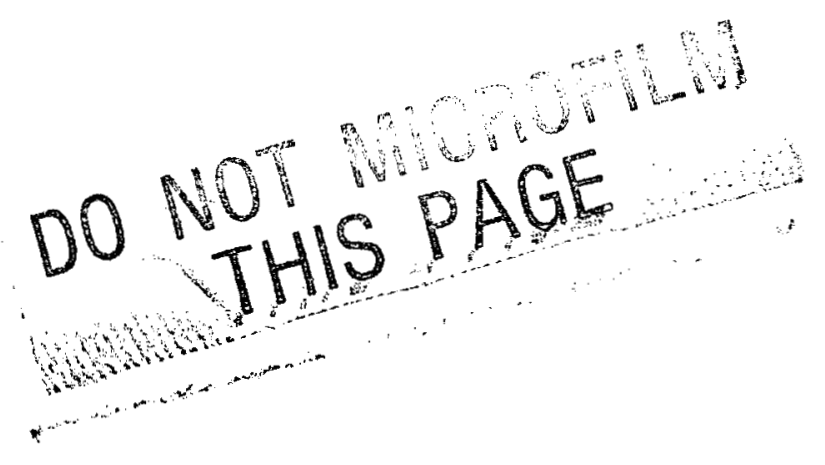




\section{NOTES}

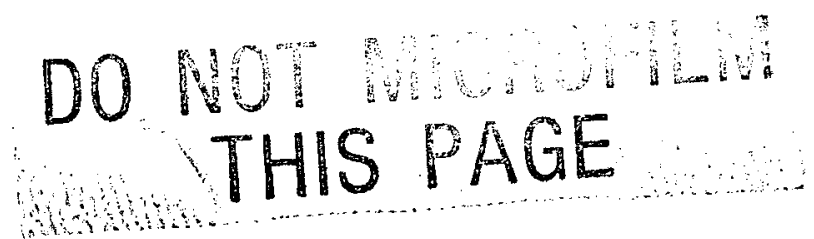




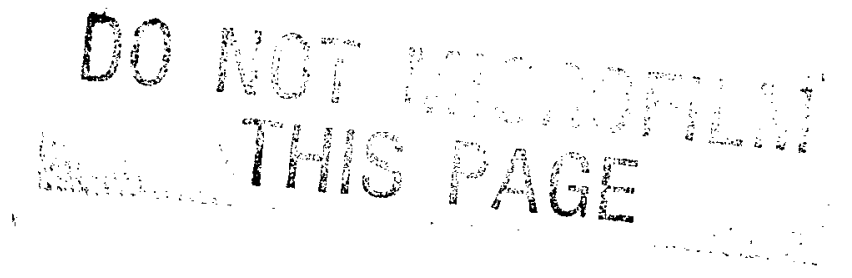

Printed in the United States of America

Available from

National Technical Information Service

US Department of Commerce

5285 Port Royal Road

Springfield, VA 22161

Microfiche (A01)

\begin{tabular}{cc} 
Page Range & $\begin{array}{c}\text { NTIS } \\
\text { Price Code }\end{array}$ \\
\hline $001-025$ & A02 \\
$026-050$ & A03 \\
$051-075$ & A04 \\
$076-100$ & A05 \\
$101-125$ & A06 \\
$126-150$ & A07
\end{tabular}

\begin{tabular}{cc} 
Page Range & $\begin{array}{c}\text { NTIS } \\
\text { Price Code }\end{array}$ \\
\hline $151-175$ & A08 \\
$176-200$ & A09 \\
$201-225$ & A 10 \\
$226-250$ & A11 \\
$251-275$ & A 12 \\
$276-300$ & A13
\end{tabular}

\begin{tabular}{cc} 
Page Range & $\begin{array}{c}\text { NTIS } \\
\text { Price Code }\end{array}$ \\
\hline $301-325$ & A 14 \\
$326-350$ & A 15 \\
$351-375$ & A 16 \\
$376-400$ & A 17 \\
$401-425$ & A 18 \\
$426-450$ & A19
\end{tabular}

\begin{tabular}{cc} 
Page Range & $\begin{array}{c}\text { NTis } \\
\text { Price Code }\end{array}$ \\
\hline $451-475$ & A20 \\
$476-500$ & A21 \\
$501-525$ & A22 \\
$526-550$ & A23 \\
$551-575$ & A24 \\
$576-600$ & A25 \\
$601-$ up* & A99
\end{tabular}

"Contact NTIS for a price quote. 


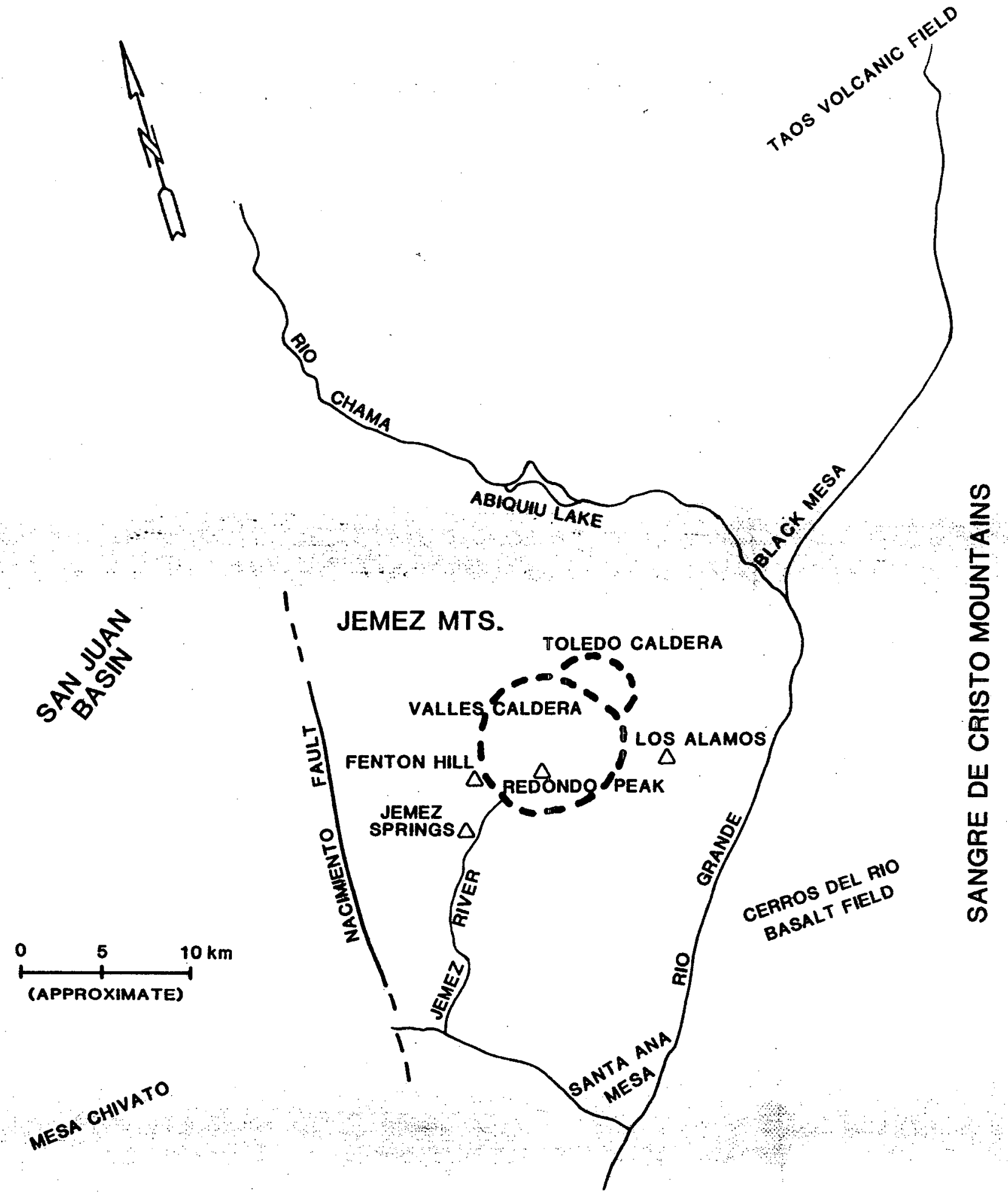

